\title{
Rare-Metal (In, Bi, Te, Se, Be) Mineralization of Skarn Ores in the Pitkäranta Mining District, Ladoga Karelia, Russia
}

\author{
Vasily I. Ivashchenko
}

check for

updates

Citation: Ivashchenko, V.I.

Rare-Metal (In, Bi, Te, Se, Be) Mineralization of Skarn Ores in the Pitkäranta Mining District, Ladoga Karelia, Russia. Minerals 2021, 11, 124. https://doi.org/10.3390/ $\min 11020124$

Academic Editor: Vasilios Melfos Received: 3 December 2020 Accepted: 25 January 2021 Published: 27 January 2021

Publisher's Note: MDPI stays neutral with regard to jurisdictional claims in published maps and institutional affiliations.

Copyright: (C) 2021 by the author. Licensee MDPI, Basel, Switzerland. This article is an open access article distributed under the terms and conditions of the Creative Commons Attribution (CC BY) license (https:/ / creativecommons.org/licenses/by/ $4.0 /)$.
Institute of Geology KarRC RAS, 185910 Petrozavodsk, Russia; ivashche@krc.karelia.ru

\begin{abstract}
The results of the study of rare-metal (Bi, Te, Se. Be, In) mineralization of skarn deposits (Sn, Zn) in the Pitkäranta Mining District, genetically related to the Salmi anorthosite-rapakivi granite batholiths of Early Riphean age are reported. Minerals and their chemical composition were identified on the base of optical microscopy as well as electron microanalysis. The diversity of rare-metal ore mineralization (native metals, oxides, and hydroxides, carbonates, tellurides, selenides, sulfides, sulphosalts, borates, and silicates) in Pitkäranta Mining District ores is indicative of considerable variations in the physicochemical conditions of their formation controlled by the discrete-pulse-like supply of fluids. Bismuth, wittichenite, and matildite are the most common rare-metal minerals. Sulfosalts of the bismuthinite-aikinite series are represented only by its end-members. The absence of solid solution exsolution structures in sulfobismuthides suggests that they crystallized from hydrothermal solutions at low temperatures. Be ( $>10$ minerals) and In (roquesite) minerals occur mainly in aposkarn greisens. Roquesite in Pitkäranta Mining District ores formed upon greisen alteration of skarns with In released upon the alteration of In-bearing solid sphalerite $\left(\mathrm{Cu}^{1+} \mathrm{In}^{3+}\right) \leftrightarrow$ $\left(\mathrm{Zn}^{2+}, \mathrm{Fe}^{2+}\right)$ and chalcopyrite $\mathrm{In}^{3+} \leftrightarrow \mathrm{Fe}^{3+}$ and $2 \mathrm{Fe}^{3+} \leftrightarrow\left(\mathrm{Fe}^{2+}, \mathrm{Zn}^{2+}\right) \mathrm{Sn}^{4+}$ solutions. Sphalerite with an average In concentration of 2001 ppm, is a major In-bearing mineral in the ores.
\end{abstract}

Keywords: Pitkäranta Mining District; skarns; aposkarn greisens; roquesite; bismuth; bismuth minerals; helvite group minerals

\section{Introduction}

The Pitkäranta Mining District (PMD) is located on the northeastern shore of Lake Ladoga, NW Russia (Figure 1). It extends for $\sim 40 \mathrm{~km}$ from north to south at the western exocontact of the Salmi anorthosite-rapakivi granite batholiths (SARGB). Copper ore was first reported from the Pitkäranta area in the late 18th century, and the discovery of the Pitkäranta deposit, followed by its mining, dates back to 1810 [1]. There were over 50 active $\mathrm{Fe}, \mathrm{Cu}, \mathrm{Sn}, \mathrm{Ag}$ mines in the PMD in 1832-1904 [2]. Tin was discovered in PMD skarns in 1834 [3]. 

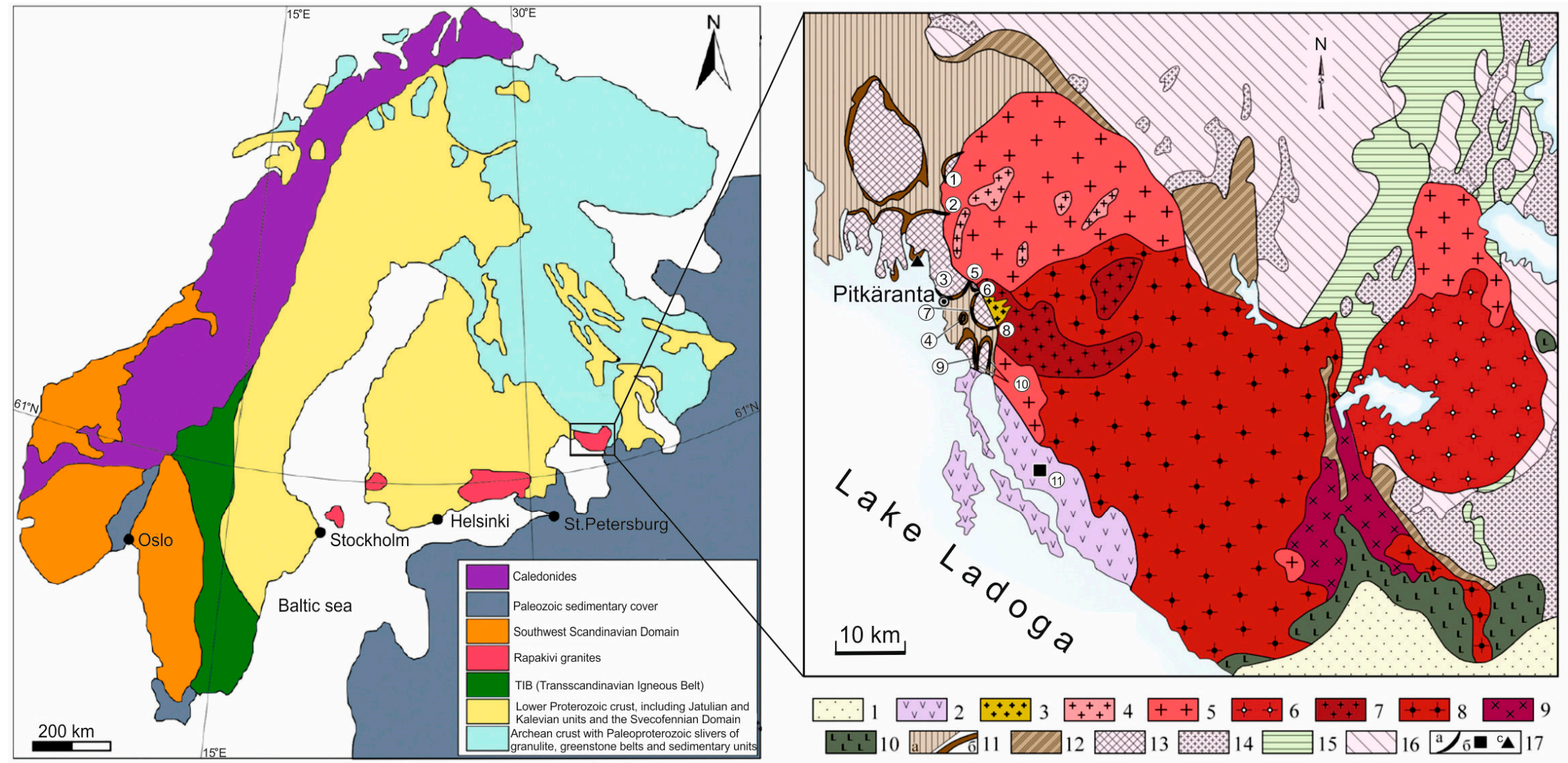

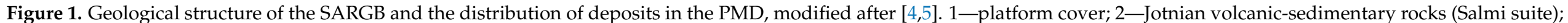

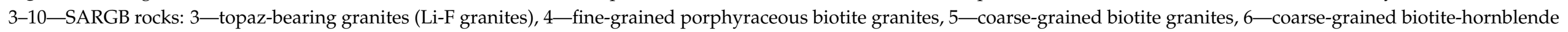

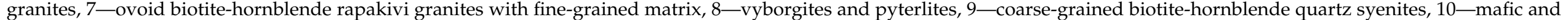

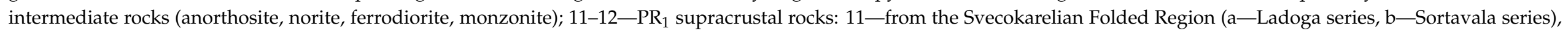

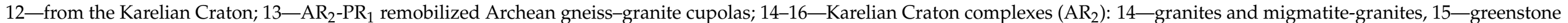

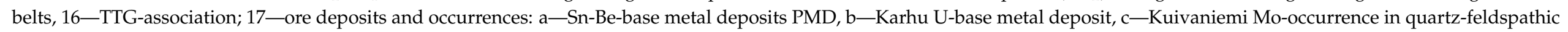

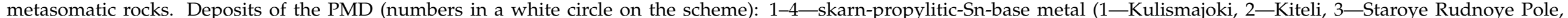

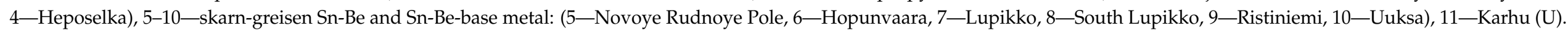


In the 200 -year period of the mining and study of skarn ore rocks of the PMD which preceded our investigation $1.1 \mathrm{Mt}$ of ore ( $\sim 500 \mathrm{t}$ of tin, $\sim 7000 \mathrm{t}$ of copper, $\sim 60,000 \mathrm{t}$ of iron, and $\sim 11 \mathrm{t}$ of silver containing about $16 \mathrm{~kg}$ of gold) were produced, three new minerals: berborite [6], fluorvesuvianite [7] and hydroxylchondrodite [8] were discovered and over 50 ore minerals: magnetite, chalcopyrite, sphalerite, pyrite, cassiterite, stokesite, eakerite, scheelite, native bismuth, arsenopyrite, löllingite, mushketovite, wickmanite, schoenfliesite, fluoborite, native gold, electrum, native silver, helvite, ludwigite, suanite, etc. [2,9-11]. In recent past few years some rare minerals, e.g., roquesite, were discovered in PMD ores [12-15].

The rapakivi granites of the SARGB are A-type granites, as indicated by their geochemical characteristics. Rapakivi plutons in the Fennoscandian Shield were occasionally described as metallogenically barren in previous literature $[16,17]$ although their genetic relation to Fe-Cu-Sn-Zn mineralization at PMD has been established much earlier $[2,18]$. The ore-forming potential of rapakivi granites on a global scale was firstly evaluated by the end of the 20th century, with several economic deposits of various types considered to be genetically associated with them [5], including unusually large tin deposits in Brazil $[19,20]$. Revealing indium (roquesite) mineralization in greisens from Vyborg Batholith rapakivi granites [21,22], in the skarns of the PMD [12,23], and economic concentrations of In, Bi, Be and $\mathrm{Cd}$ and other rare metals in PMD ores [13], provided another argument in favor of the metallogenic potential of rapakivi granites. Using up-to-date analytical methods, it has become possible to infer some formation characteristics of roquesite, bismuth sulfosalts, and helvite-group minerals during multi-stage skarn and ore formation related to the multiple discontinuous additions of hydrothermal solutions generated by SARGB granitoid formed by six magmatic pulses [5].

However, mineralogical description of PMD skarn ores, presented in many publications [10-15,24-26], covers mainly Sn-, Cu-, Zn-, and Fe-bearing minerals with few exceptions. In the present paper, the minerals of rare-metals (In, Bi, Be, Te, Se) and new metallogenic prospects of the PMD are described. Peculiarities of rare metal mineralization in propylitized skarns of deposits with $\mathrm{Fe}-\mathrm{Sn}-\mathrm{Zn}-\mathrm{Cu}$ ores and in aposkarn greisens (greisenized skarns ) of deposits with Fe-Sn-Zn-Be ores are considered. The features of the distribution of roquesite in skarn ores are shown.

\section{Geological and Metallogenetic Background}

The modern geological structure of the PMD as the eastern flank of the Ladoga Structure is the result of its long ( $>1 \mathrm{Ga})$ evolution, which comprised continental and ocean margin rift formation with the opening of the Svecofennian ocean followed by the convergent interaction of the newly-formed oceanic crust with the Archean craton [23,27]. Correspondingly, the formation of structural-mineralogical complexes in the province was subdivided into several stages terminated by the closing of the ocean followed by the formation of an accretionary-collisional orogen, post-collisional uplift, cratonization, and Mesoproterozoic intraplate discrete magmatism [23].

Archean basement rocks (gneiss, granite-gneiss, amphibolite; $2.7-2.66 \mathrm{Ga}$ ) have preserved only as so-called «rimmed granite-gneiss domes» after P. Eskola [28] rimmed by the volcanic-sedimentary rocks of the Pitkäranta suite (Ludicovian, 2.1-1.92 Ga) overlain by Ladoga turbidites (Kalevian, 1.92-1.8 Ga) (Figures 1 and 2). The Pitkäranta suite section is dominated by ortho- and para-amphibolites, amphibole, mica and graphite schists, locally quartzites and carbonate rocks (dominantly dolomites or their calcitized varieties) transformed to marble, carbonate-silicate rock, and skarn. They have traced on the margins of gneissose granite domes as 200-500 m thick, locally discontinuous zones (Figures 1 and 2). The carbonate rocks of the suite are represented by two horizons totaling $40-120 \mathrm{~m}$ in thickness. 


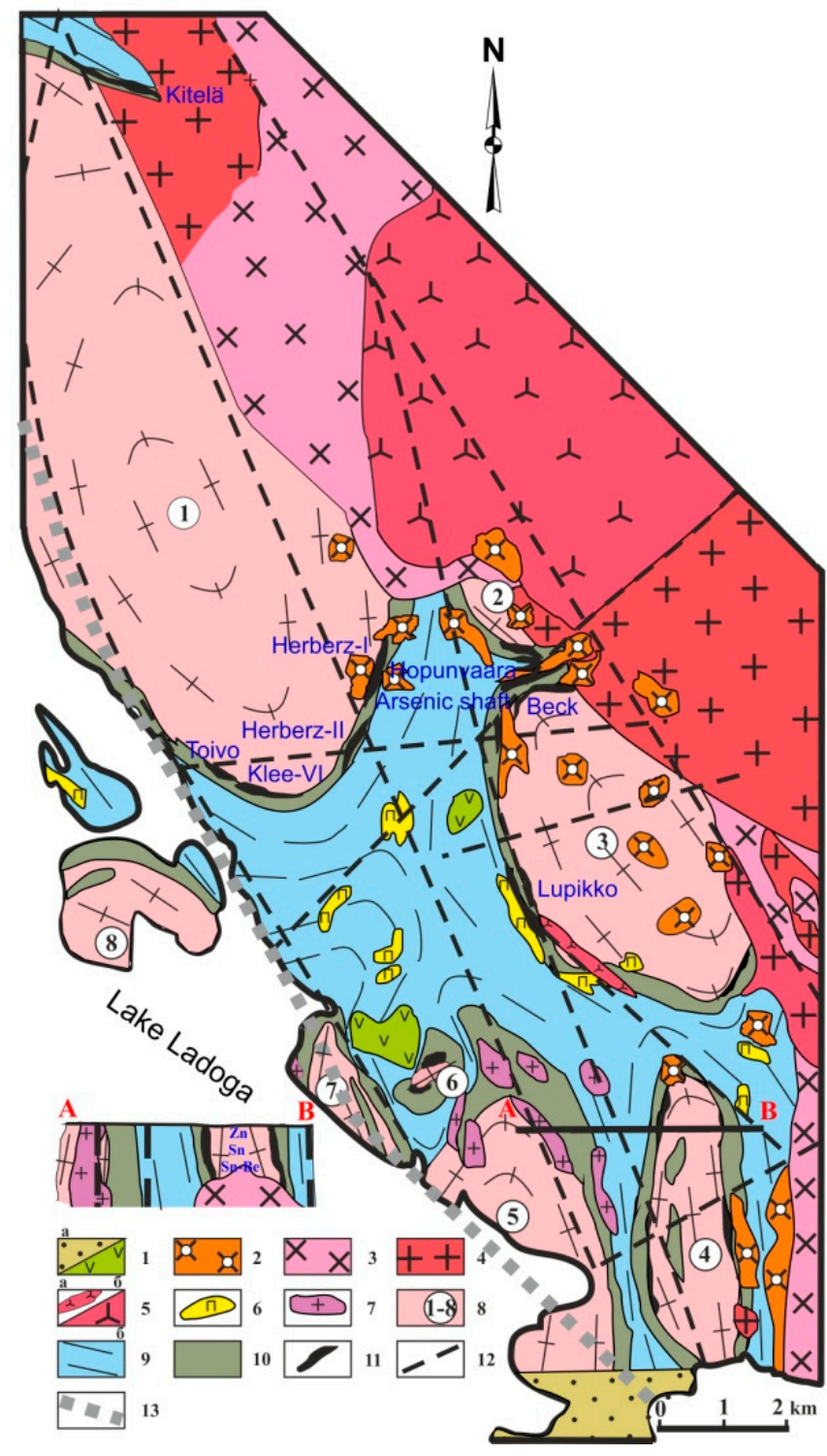

Figure 2. Scheme showing the geological structure of the PMD, modified after [2,29]. 1-Salmi suite: A-sandstones, conglomerates, $\mathrm{b}$-basalts, dolerites; 2-5-rapakivi granites: 2-leucogranites and lithium-fluorine granites, 3-fine-grained granites, 4-medium-grained porphyritic biotite granites, 5a-granite-porphyry, 5b-porphyritic amphibole-biotite granites; 6-pegmatites; 7—synorogenic plagiogranites, granodiorites; 8-remobilized Archean gneissose granitic domes (1-Pitkäranta, 2-Vinberg, 3-Lypikko, 4-Uuksa, 5-Ristiniemi, 6-Heposelka, 7-Juläristi, 8-Pusunsaari); 9Ladoga series: biotite-quartz, quartz-feldspathic-biotite and graphite-bearing schists; 10_Pitkäranta suite: Amphibolites, amphibole, graphite and graphite-bearing schists, dolomitic and calcitic marbles and skarns after them; 11—skarns, greisenized skarns and low-temperature metasomatic rocks after them with Fe-Cu-Zn-Sn mineralization and rare-metal mineralization; 12-tectonic dislocations; 13-projection onto the modern erosion surface of the boundary of the sharp bend of the top of the Salmi massif (it delineates the skarn zone with Fe-Cu-Zn-Sn mineralization).

Ludicovian and Kalevian rocks in the PMD were metamorphosed under amphibolitefacies conditions and are cut by Svecofennian (syn- and post-orogenic) granites and pegmatites as well as the SARGB of Riphean age (1530-1547 Ma) [5,30,31]. In the southern part of the province, all the above structural-mineralogical complexes are overlain by Jotnian volcanic-sedimentary rocks (Salmi suite, $1.48 \mathrm{Ga}$ ) (Figures 1 and 2). 
The SARGB $\left(\mathrm{S}=\sim 5000 \mathrm{~km}^{2}\right)$ is confined to a conjugate zone between the Mesoproterozoic Svecofennian accretionary-collisional orogen and the Archean Karelian Craton (Figure 1). The batholith intruded along an overthrust zone between these tectonic structures. It consists of the Salmi massif proper located in the folded region and its satellite, the Ulälega massif located in craton rocks (Figure 1). The batholith cross-cuts Archean granitoids and greenstone belts as well as Lower Proterozoic (Jatulian, Ludicovian, and Kalevian) supracrustal rock complexes. The batholith was produced by six discrete intrusion pulses of mafic and felsic magma throughout $\sim 17 \mathrm{Ma}(1546.7 \pm 1.7-1529.9 \pm 0.6)[5,30,31]$. In the southwestern portion, the batholith is cut by subvolcanic basic rock bodies-which are comagmatic to the Salmi basalts dated at 1457-1459 Ma [32], and in the northeastern portion, it is cut by moderately medium-basic alkaline rock dikes of the Enäjoki complex. Their age is unknown.

Geophysical data show that the SARGB is a subhorizontal lamina-like body varying in thickness from $2 \mathrm{~km}$ in its northwestern portion to $10 \mathrm{~km}$ in its southeastern portion $[4,33]$. The rocks are succeeded consistently in the same direction with an increase in their basicity and age (Figure 1).

Batholith granitoids are tentatively subdivided into three groups $[5,26,34]$ distinguished earlier [26,34] as intrusion phases dominated by the two former groups: (1) biotiteamphibole granites, (2) biotite granites and (3) topaz-bearing Li-F granites. The latter form small stock-like bodies and dikes, whose apical and endocontact zones typically display striated textures (Figure 3) and stockscheiders. The dark-colored minerals (biotitelepidomelane, protolithionite, ferrohastingsite, ferrohedenbergite, fayalite) of all three groups of granitoids are characterized solely by high iron concentration $[\mathrm{Fe} /(\mathrm{Fe}+\mathrm{Mg})]$ 0.8-1.0. Accessory minerals are commonly represented by fluorite, zircon, apatite, ilmenite, magnetite, anatase, allanite, uraninite, and thorite. Granites of the second and third groups also contain monazite, bastnäsite, topaz, cassiterite, rutile, ilmenorutile, columbite, pyrochlore, and thorianite.

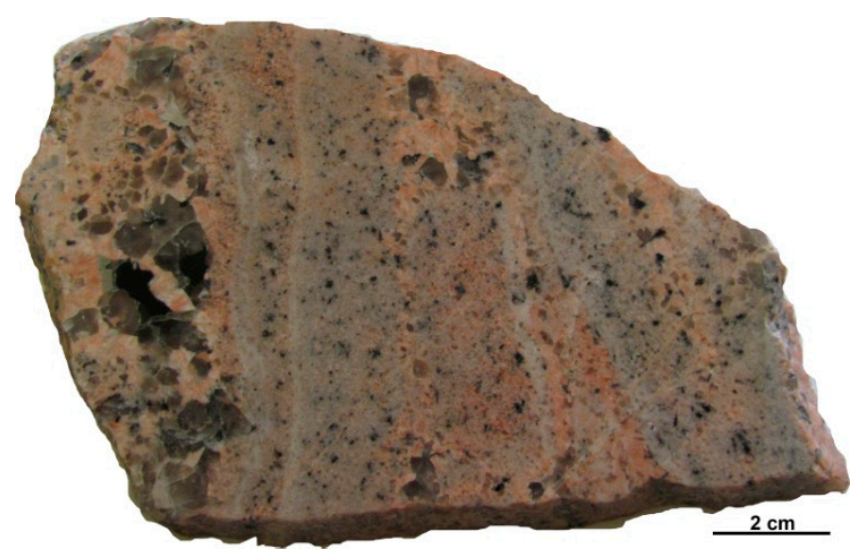

Figure 3. Striped (layered) texture of Li-F-granites (polished hand specimen). (Lypikko).

Skarn deposits and occurrences in the PMD are located at the western gently plunging exocontact of the SARGB in a zone composed of the most differentiated rapakivi granites (Figure 2). The geological map of the province was compiled by A.E. Tornebom [16]. More details were added by $\mathrm{O}$. Trustedt [2], who completed the map, which has mainly remained unchanged to the present day. The above geologists proposed a skarn model of PMD ore formation, where the carbonate rock horizons were affected by hydrothermal fluids supplied from the SARGB. The model was supported later by most researchers and was further updated [5,24-26,34-37].

In these deposits, the following generalized zoning of ore-bearing metasomatic rocks from the top of the massif is observed: altered skarns-Fe-Zn-Sn-Cu; aposkarn greisensSn-Zn-Be-fluorite $( \pm \mathrm{Cu})$; low-temperature aposkarn metasomatic rocks- $\mathrm{Sn}, \mathrm{Pb}, \mathrm{Zn}( \pm \mathrm{Cu})$. This zoning, affected by many factors, is either disturbed locally or does not manifest itself 
at all but generally persists for the PMD [29,34,38,39]. In this case, all aposkarn metasomatic rocks are not ubiquitous in the skarns but evolve in them along linearly elongated zones up to several meters in thickness or less commonly form shapeless and columnar bodies with veined ramifications up to $4-5 \mathrm{~m}$ in thickness. Aposkarn greisens are spatially associated with Li-F-granite bodies and feldspathic or quartz-feldspathic metasomatic rocks and fluorite-quartz-mica greisens evolving after gneissose granites and granites.

Geochronological data ( $\mathrm{Sm}-\mathrm{Nd}$ mineral isochrones for tin-bearing skarns from the Kitteli deposit) suggest conditionally two stages of ore formation in skarns: $1558 \pm 30 \mathrm{Ma}$ and $1546 \pm 28 \mathrm{Ma}[5,29]$.

The skarn ore bodies formed after Pitkäranta carbonate rocks rimming remobilized Archean gneissose granite domes (Figure 2). The skarns are propylitized almost everywhere and are greisenized at some places. Depending on the degree of greisen alteration, the skarns display Sn-Cu-base metal mineralization with magnetite (Pitkäranta dome-Old Ore Field, Kittelä; Heposelkä and Kulismajoki domes)—poor or no greisenization and Be-Sn-base metal with fluorite and magnetite (Pitkäranta dome-New Ore Field; Lupikko, Uksa, and Ristiniemi domes) — greisenization is strong. Sn-Cu-base metal deposits, bigger than Be-Sn-base metal deposits, occur in the exocontact zone of the massif, whose top plunges steeply (Kittelä) or are confined to the steep bend of the top, where a gentle bend passes into subvertical (Old Ore Field, Heposelka). The top of granites in such zones is at a depth of $1 \mathrm{~km}[26,33]$. Be-Sn-base metal deposits are commonly located above Li-F granite domes unexposed by erosion and are spatially associated with the dikes of these granites and stockscheiders.

The ore bodies display irregular lenticular and sheet-like shapes caused by the morphology of skarn bodies that often exhibit complex structures resulting from the heterogeneous composition and structure of original carbonate units and the overlapping of ore-bearing metasomatic rocks formed at the various stages of mineral formation. The types of ore-bearing metasomatic rocks recognized in the deposits of the PMD are [26,29,34-36]: magnesian skarns formed at magmatic and postmagmatic stages, calcareous apomagnesian skarns, aposkarn greisens (fluorite-vesuvianite-magnetite, fluorite-mica and magnetitefluorite-mica), and propylites, feldspathic, and quartz-carbonate metasomatic rocks.

Magnesian skarns commonly occur only as relics among the lime skarns that replace them. They are best-preserved at the Kulismajoki occurrence at the margin of the Kulismajoki gneissose granite dome (Figure 1) [34]. Concomitant Fe and Zn mineralization is associated with magnesian skarns. Calcareous apomagnesian skarns (the dominant type of metasomatic rocks at PMD deposits) commonly host Fe-Zn and Sn-mineralization. In addition to cassiterite, considerable quantities of tin in these skarns are concentrated in the isomorphic form in garnets $[4,14,26,29,34]$, where tin concentrations are as high as $2.7 \%$ [14]. Hopunvaara calcareous apomagnesian skarns, subjected to greisen transformations, and converted to fluorite-phlogopite-vesuvianite-magnetite metasomatic rocks, display a rhythmically striated structure (Figure 4).

Associated with aposkarn greisens is beryllium mineralization; the bulk of Be (up to $0.85 \%$ ) is concentrated in vesuvianite [5]. Greisens often exhibit tungsten (scheelite) and Mo mineralization. Some molybdenite crystals are 5-6 cm across. Gradual transitions of aposkarn greisens to propylites are occasionally observed.

Original carbonate units are thin and display a heterogeneous composition and structure. Therefore, persistent ore bodies are mainly confined to steeply dipping skarn bodies. The central highest-grade portions of the ore bodies occur practically at the same hypsometric level for most deposits of the province. Confined to this surface are $\mathrm{Sn}$ - and Be-Sn ore columns mainly oriented sub horizontally in the carbonate bed plane. This is probably due to the ore deposition pattern in zones where steeply dipping ore-feeding channels are intersected by lit-par-lit ore-controlling dislocations in carbonate horizons [5]. The most significant tin deposits are Kitelä, Uuksa, and Hopunvaara [40,41], and the most significant base metal deposit is Hopunlampi. 


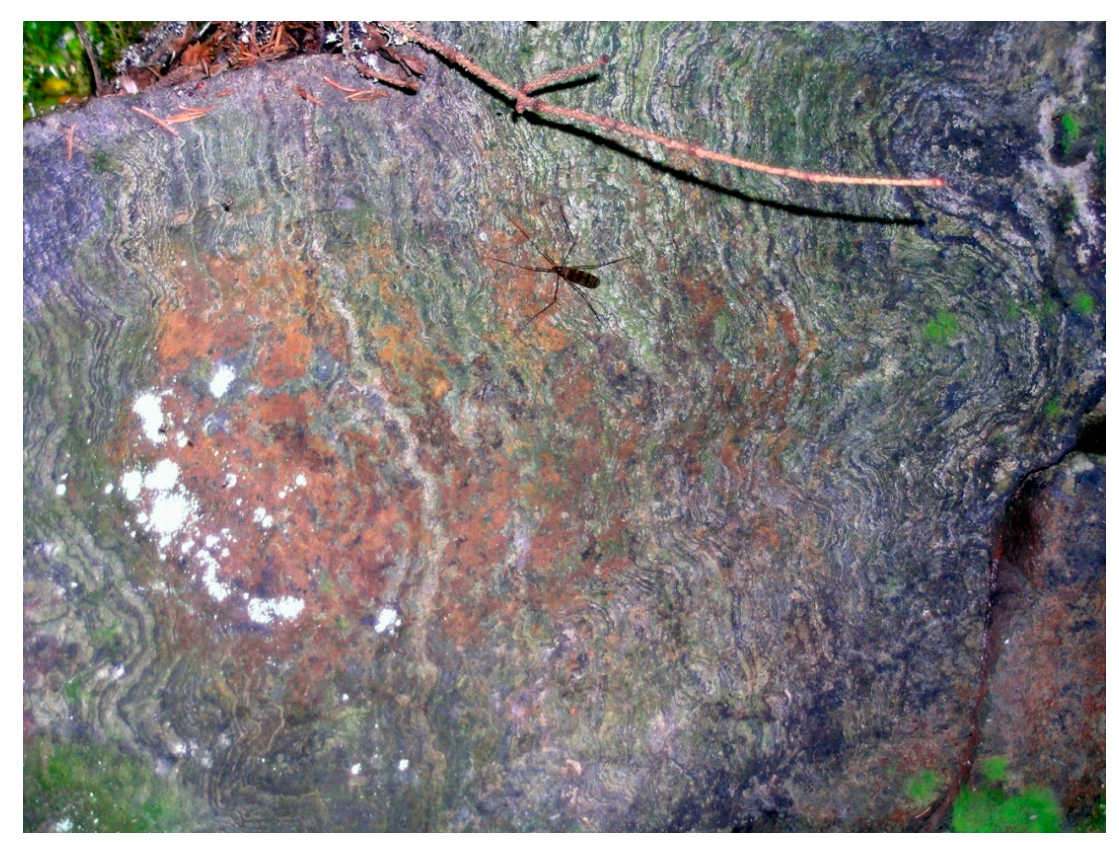

Figure 4. Greisenized rhythmically striped apomagnesian calcareous skarns (Hopunvaara). Dark areas: magnetite, sphalerite, spinel, chondrodite, phlogopite, serpentine; light areas: fluorite, vesuvianite, garnet, gahnite, calcite, cassiterite, scheelite.

Geochronological data on PMD ore-bearing skarns [29,42,43] support the 19th and early 20th geological concepts [2,16], according to which they are genetically related to SARGB granites. The results of $\mathrm{Pb}$-isotope systematics of ores and magmatic rocks from the PMD $[30,37,44]$ are indicative of a common source of ore matter in the skarn deposits and rapakivi granites of the SARGB. However, molybdenite mineralization in skarns seems to be of polygenic-polychronic origin. The age of molybdenite from Li-F granites (1575 Ma, ReOs) [45] is similar to the lower age boundary (1547 Ma) of Salmi pluton granite intrusion and much older than molybdenites from Old Ore Field and Kitelä skarns (1827-1763 Ma). This age seems to be consistent with the timing of the formation of Svecofennian granites and pegmatites occurring in the province. This seems to partly corroborate the correctness of M. Saksela's [25] three-stage model for the formation of PMD ores: stage I with pegmatites and stages II and III with rapakivi granites.

\section{Materials and Methods}

Rare-metal mineralization was studied using samples taken by the author in 1978-1980 and 2008-2016 from ore-bearing skarn exposures, prospecting workings, mine dumps, and drill cores (not preserved). Polished sections for Kitelä, stored at the Regional Geological Archives, Republic of Karelia, were also analyzed. A total of over 200 samples from the Old and New Ore Fields of the Pitkäranta deposit, the Hopunvaara and Lupikko Ore Fields, the Kitelä deposit as well as the Kulismajoki, Heposelka and Avtodor occurrences were analyzed. Specimens for ICP MS analysis were prepared from all samples and polished sections were made. The polished sections were studied by optical microscopy (an Axiolabpol-u optical microscope equipped with a digital photographic camera and a computer) at the Institute of Geology, Karelian Research Centre, Russian Academy of Sciences.

The minerals were all analyzed at the Centre for Team Use, Karelian Research Centre, RAS, Petrozavodsk, Russia. The minerals' composition was analyzed in polished thin sections with a VEGA II LSH Scanning Electron Microscope (Tescan, Brno, Czech Republic) at the Centre for Collective Usage Karelian Research Centre (Petrozavosdk, Russia). The instrument was equipped with an energy dispersive spectrometry (EDS) Energy 350 system and an SDD X-Act3 detector (Oxford Inca Energy, Oxford, UK). Operating conditions were: $20 \mathrm{kV}$ accelerating voltage, $5 \mathrm{nA}$ probe current, $1 \mu \mathrm{s}$ EDS process time, $105 \mathrm{cnts} / \mathrm{s}, 30 \mathrm{~s}$ 
counting time. The spectral lines for each element are $\mathrm{CuK} \alpha, \mathrm{FeK} \alpha, \mathrm{ZnK} \alpha, \mathrm{MnK} \alpha, \mathrm{SK} \alpha$, $\mathrm{FK} \alpha, \operatorname{InL} \alpha, \operatorname{AgL} \alpha, \operatorname{AuL} \alpha, \operatorname{Te} \alpha \alpha, \operatorname{SeL} \alpha, \operatorname{SnL} \alpha, \operatorname{AsL} \alpha, \operatorname{BiM} \alpha, \operatorname{PbM} \alpha, \mathrm{WM} \alpha$. The following standards were used: $\mathrm{CaCO}_{3}, \mathrm{CaF}_{2}, \mathrm{FeS}_{2}, \mathrm{PbTe}, \mathrm{HgTe}, \mathrm{TlSbSe}_{2}$, InAs, $\mathrm{NaCl}, \mathrm{Cu}, \mathrm{Co}, \mathrm{Ni}, \mathrm{Zn}$, $\mathrm{Mn}, \mathrm{As}, \mathrm{Se}, \mathrm{Ag}, \mathrm{Au}, \mathrm{Sn}, \mathrm{Te}, \mathrm{W}, \mathrm{Bi}$. SEM-EDS quantitative data and determination of the analysis accuracy were acquired and processed using the Microanalysis Suite Issue 12, INCA Suite version 4.01; standard deviation (S) for $\mathrm{In}-0.6-1.8 \%$, Pb-1.3-4.4\%, $\mathrm{Bi}-0.8-4.2 \%$, $\mathrm{Te}-0.4-2.0 \%$, Se-0.4-1.3\%, Cu-0.7-2.3\%, Zn-1.0-2.4\%, Ag-0.3-2.3\%, S-0.4-0.7\%.

Trace elements in sphalerite and chalcopyrite were identified by the LA-ICP-MS method on an X-SERIES-2 quadrupole mass-spectrometer (Thermo Scientific, Waltham, MA, USA) equipped with a UP-266 Macro Laser Ablation attachment (New Wave Research, MODEL UP266 MACRO AT, Fermont, CA, USA) in the IG KSC RAS (analyst A.S.Paramonov) following the method [46]. The Nd:Yag laser operates with a wavelength of $266 \mathrm{~nm}$ and energy output of $0.133 \mathrm{~mJ}$ (scan speed $70 \mu \mathrm{m} / \mathrm{sec}$, impulse frequency $10 \mathrm{~Hz}$ ). All measurements were carried out with identical parameters. Standard NIST 612 was used for calibration procedures. The measured trace element concentration values are characterized following parameters of relative standard deviation (RSD): for transition metals (Co, Mn, Cr, V, Cu, Zn) $<15 \%$, for As $<20 \%$, for In, Cd $<25 \%$.

Trace, rare earth, and transition element concentrations ( $\mathrm{V}, \mathrm{Cr}, \mathrm{Co}, \mathrm{Ni}, \mathrm{Rb}, \mathrm{Sr}, \mathrm{Y}, \mathrm{Zr}, \mathrm{Nb}$, $\mathrm{Ba}, \mathrm{Hf}, \mathrm{Ta}, \mathrm{Pb}, \mathrm{Th}$, and $\mathrm{U} ; \mathrm{V}, \mathrm{Cr}, \mathrm{Co}, \mathrm{Ni}, \mathrm{Rb}, \mathrm{Ta}$, and $\mathrm{Pb}$ concentrations were measured for some samples) were determined by mass spectrometry with inductively coupled plasma (ICP-MS). Element abundances were measured on a Thermo Scientific X-Series 2 ICP-MS quadrupole mass spectrometer (Thermo Scientific, Waltham, MA, USA) after [46], at the Analytical Center of the Institute of Geology, Karelian Research Center, Russian Academy of Sciences (KarRC RAS, Petrozavodsk, Karelia, Russia). Analyses were performed on $100 \mathrm{mg}$ subsamples, which were decomposed by the acid breakdown in an open system. Samples were decomposed with high purity acids $\left(70 \% \mathrm{HClO}_{4}, 65 \% \mathrm{HNO}_{3}, 40 \% \mathrm{HF}\right)$, additionally purified by distillation in a PTFE/PFA SubboilingEcoIR acid distillatory manufactured by the High-Purity Standards Company (North Charleston, SC, USA), and deionized water. ICP-MS calibration was performed using a 68-(ICP-MS-68A-A) and 13-element (ICP-MS-68A-B) standard solutions manufactured by the High-Purity Standards Company. The study samples, reference samples, and blank samples were measured in groups of 15-20 with the measurements of calibration blocks to detect instrument drift in the interim. The SGD-2A, S-1412, and BHVO2 standard rock samples were used as certified reference samples. The measured concentration values are characterized by low relative standard deviation (RSD) values; the percentages are lower than $7 \%$ for most elements and $7-12 \%$, for $\mathrm{Co}, \mathrm{Ni}, \mathrm{Y}$, and $\mathrm{Ta}$.

\section{Mineralogy and Mineral Chemistry-Results}

Rare-metal mineralization in the ores of PMD is mainly represented by the minerals In, $\mathrm{Bi}, \mathrm{Be}, \mathrm{Te}$ and Se. They commonly occur only in skarns subjected to greisen, propylitic and lower-temperature metamorphism. They are much inferior in the quantity and size of aggregates in comparison to major (magnetite, sphalerite, chalcopyrite, cassiterite, and pyrite) and minor (arsenopyrite, löllingite, bornite, galena, cubanite, scheelite, molybdenite, stokesite, wickmanite, and schoenfliesite) ore minerals.

\subsection{Roquesite $\left(\mathrm{CuInS}_{2}\right)$}

The first evidence for the presence of indium in PMD skarn ores dates back to the early 19th century [47]. It was supported more recently [48] by numerous analyses, but In-bearing minerals and roquesite were identified much later [25] and [12-15].

Roquesite, was found in high-grade indium (up to $0.33 \mathrm{wt} . \%$ ) tin-copper-base metal ores of aposkarn greisens (Hopunvaara, Arsenic Shaft) and propylitized skarns (Kitelä). Samples of aposcarn greisens with roquesite contain 119-3300 ppm In. Sample of propylitized skarn with roquesite contain $15 \mathrm{ppm}$ In. Roquesite occurs in three mineral associations: streaky aggregates combined with stannoidite and individual grains in chalcopyrite (up to $30 \mu \mathrm{m}$ ) 
with thinly laminated stannite aggregates (Figure 5a-e,h,i)—Arsenic Shaft; micron-sized grains $(2-8 \mu \mathrm{m})$ at the hessite-chalcopyrite contact in sphalerite (Figure 5g) -Arsenic Shaft; microscopic intergrowths (1-2 $\mu \mathrm{m}$ ) with galena in chalcopyrite (Figure 5f)-Kitelä.deposit.
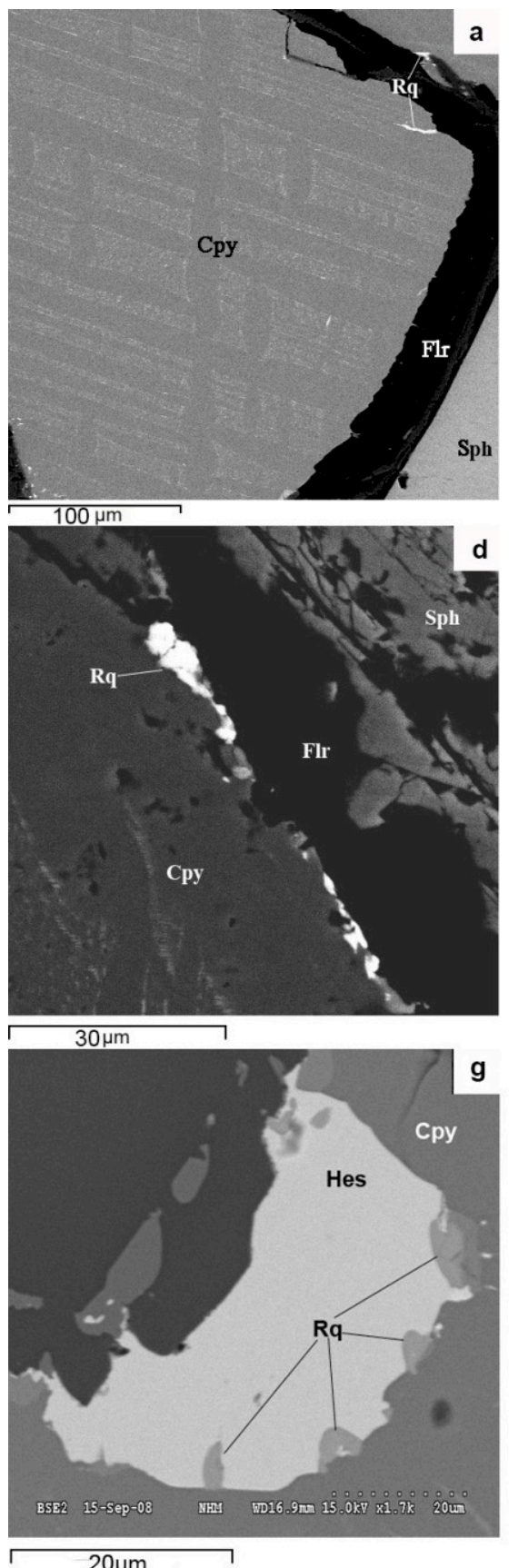
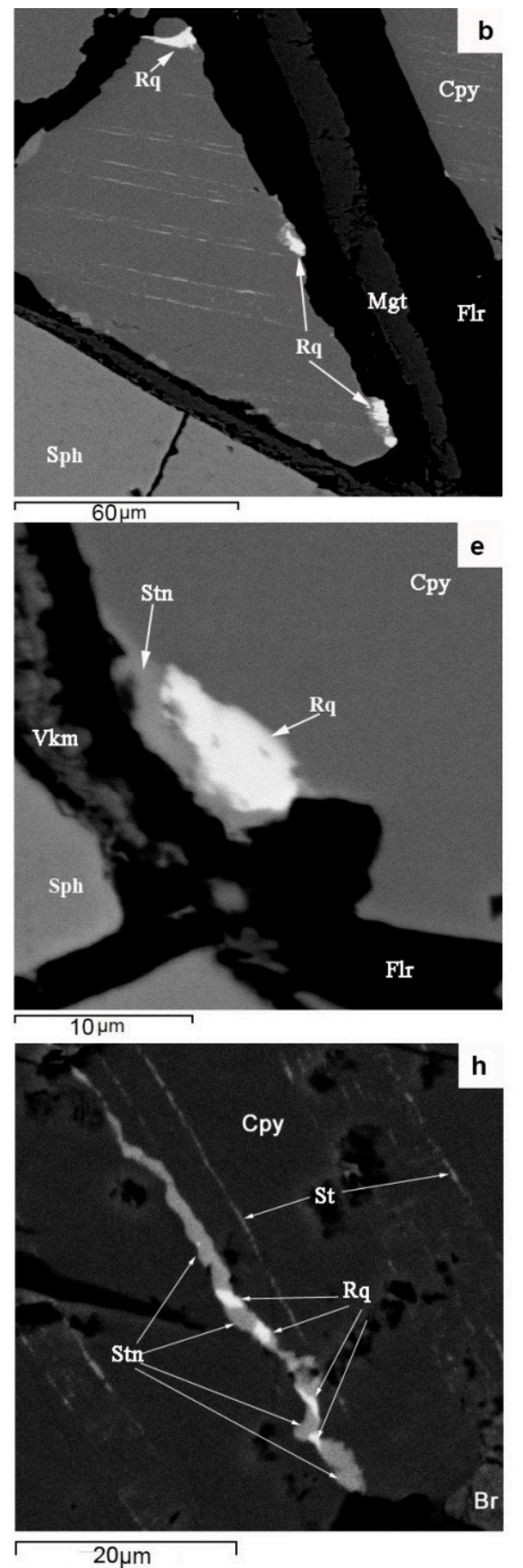
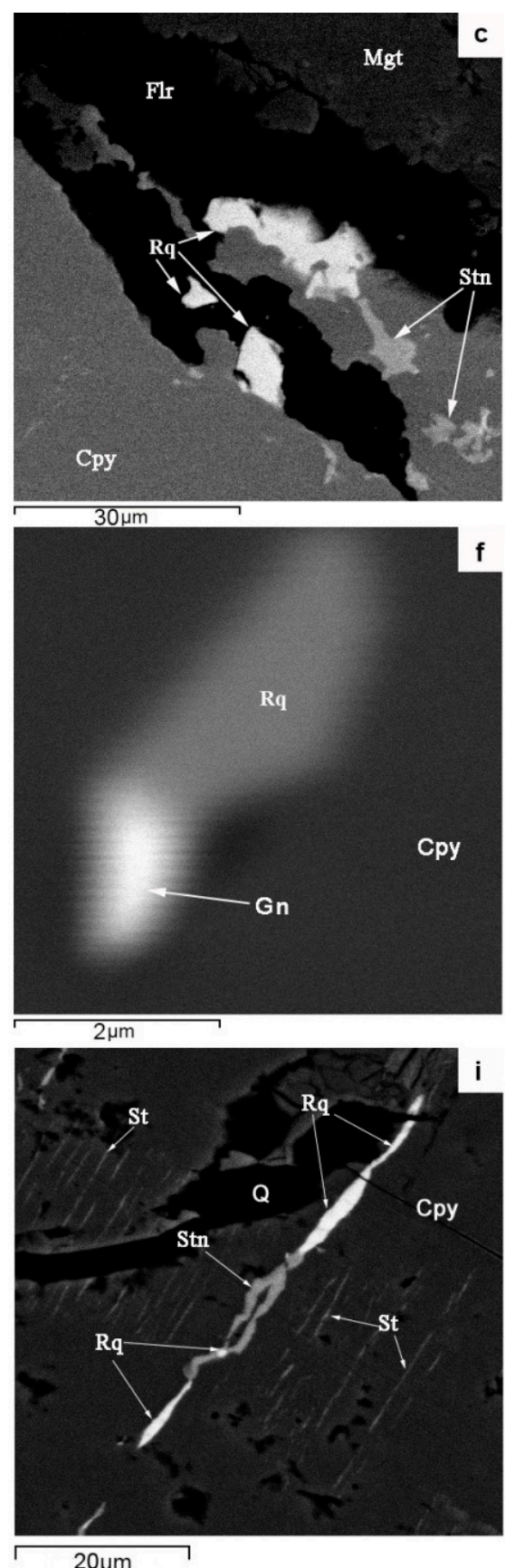

Figure 5. BSE images. Roquesite mineralization in PMD ores; for the explanation, see text. Br—bornite, Cpy—chalcopyrite, Flr-fluorite, Gn-galena, Hes-hessite $\left(\mathrm{Ag}_{2} \mathrm{Te}\right), \mathrm{Mgt}$-magnetite, Q-quartz, Rq—roquesite, Sph-sphalerite, Srpserpentine, St—stannite $\left(\mathrm{Cu}_{2} \mathrm{FeSnS}_{4}\right)$, Stn—stannoidite $\left(\mathrm{Cu}_{8} \mathrm{Fe}_{3} \mathrm{Sn}_{2} \mathrm{~S}_{12}\right), \mathrm{Vkm}$-wickmanite $\mathrm{Mn}\left[\mathrm{Sn}(\mathrm{OH})_{6}\right]$.

The mineral composition of roquesite-bearing aposkarn greisens is considerably different from that of propylitized skarns (Table 1), but the temperature range of roquesite formation in them is about the same-270-320 ${ }^{\circ} \mathrm{C}$ (stannite-sphalerite geothermometer) $[49,50]$. Greisen typically displays a great variety of minerals and an abundance of fluorite, fluorinebearing silicates, and bismuth minerals. Propylitized skarns are dominated by chlorite, 
tremolite, and diopside (relics), and high-Bi and high-F minerals are scarce (Table 1). The chemical composition of roquesite is near-stoichiometric, except for Fe impurity which is constantly present in it (Table 2) and is the highest (up to $4.52 \%$ ) in Kitelä propylitized skarns. This seems to be due to high Fe activity in hydrothermal solutions and the wide range of solid $\mathrm{CuFeS}_{2}-\mathrm{CuInS}_{2}$ solution [51]. It is also possible that some of $\mathrm{Fe}$ and $\mathrm{Zn}$ are impurities.

Table 1. Mineral composition of roquesite-bearing ore metasomatic rocks from PMD deposits.

\begin{tabular}{ccc}
\hline Aposkarn Greisens & Propylitized Skarns & $\begin{array}{c}\text { Common Minerals of Aposkarn } \\
\text { Greisens and Propylitized Skarns }\end{array}$ \\
\hline $\begin{array}{c}\text { Cubanite, idaite, chalcocite, alisonite, Ag-covellite, } \\
\text { molybdenite, emplectite, tsumoite, wittichenite, stannoidite, } \\
\text { mawsonite, jalpaite, wickmanite, schoenfliesite, scheelite, } \\
\text { angelaite, naummanite, uraninite, nasturane, chenevixite, } \\
\text { karibibite, schneiderhöhnite }\end{array}$ & $\begin{array}{c}\text { Arsenopyrite, aikinite, } \\
\text { montesite, stokesite, } \\
\text { electrum, arcubisite, } \\
\text { matildite, } \\
\text { cerussite, anglesite }\end{array}$ & $\begin{array}{c}\text { Sphalerite, löllingite, chalcopyrite, pyrite, } \\
\text { galena, bornite, native bismuth, } \\
\text { cassiterite, stannite, magnetite, hematite, } \\
\text { hessite, acanthite, native silver }\end{array}$ \\
\hline Fluorite, chondrodite, vesuvianite & Non-ore minerals & $\begin{array}{c}\text { Diopside, tremolite, } \\
\text { andradite, quartz }\end{array}$ \\
\hline
\end{tabular}

Table 2. Representative electron microanalyses and atomic proportions of roquesite.

\begin{tabular}{|c|c|c|c|c|c|c|c|c|c|c|c|}
\hline wt. $\%$ & 1 & 2 & 3 & 4 & 5 & 6 & 7 & 8 & 9 & 10 & 11 \\
\hline $\mathrm{Cu}$ & 25.01 & 25.27 & 24.73 & 25.47 & 26.54 & 26.09 & 28.38 & 26.05 & 25.81 & 26.55 & 25.21 \\
\hline In & 45.32 & 45.66 & 43.68 & 46.18 & 47.00 & 45.76 & 45.42 & 46.34 & 43.91 & 40.63 & 44.58 \\
\hline $\mathrm{Fe}$ & 1.81 & 2.08 & 1.79 & 1.35 & 0.70 & 1.73 & bd & 1.18 & 1.95 & 4.52 & 3.06 \\
\hline $\mathrm{Zn}$ & $\mathrm{bd}$ & $\mathrm{bd}$ & 3.12 & $\mathrm{bd}$ & $\mathrm{bd}$ & $\mathrm{bd}$ & bd & $\mathrm{bd}$ & 2.49 & $\mathrm{bd}$ & bd \\
\hline $\mathrm{S}$ & 26.67 & 26.44 & 25.47 & 26.49 & 26.12 & 27.33 & 27.37 & 26.75 & 27.04 & 27.21 & 27.20 \\
\hline Total & 98.81 & 99.45 & 98.79 & 99.49 & 100.36 & 100.91 & 101.17 & 100.32 & 101.20 & 98.91 & 100.05 \\
\hline \multicolumn{12}{|c|}{ Chemical formula } \\
\hline $\mathrm{Cu}$ & 0.96 & 0.97 & 0.92 & 0.97 & 1.00 & 0.97 & 1.05 & 0.98 & 0.94 & 0.98 & 0.95 \\
\hline In & 0.96 & 0.96 & 0.89 & 0.98 & 0.98 & 0.96 & 0.95 & 0.97 & 0.89 & 0.84 & 0.92 \\
\hline $\mathrm{Fe}$ & 0.08 & 0.09 & 0.08 & 0.05 & 0.02 & 0.07 & & 0.05 & 0.08 & 0.19 & 0.13 \\
\hline $\mathrm{Zn}$ & & & 0.11 & & & & & & 0.09 & & \\
\hline$S$ & 2.04 & 2.06 & 2.03 & 2.03 & 2.00 & 2.03 & 1.95 & 2.02 & 2.02 & 2.04 & 2.05 \\
\hline
\end{tabular}

1-9-Arsenic shaft; 10, 11-Kitilä; bd—below detection limit. 3, 9-probably mixed with sphalerite; Formula of the roquesite phase based on sum cations 2 .

\subsection{Native Bismuth and Bismuth Sulfosalts}

Native bismuth is widespread in PMD ore-bearing aposkarn metasomatic rocks. It is associated with practically all ore and gangue minerals and occurs as microinclusions (Figure 6a,c), and coarser aggregates (Figure 6b), and joint intergrowths with sphalerite, wittichenite, covellite, bismuthinite, altaite, native silver. Also, it often grows on minerals formed earlier (Figure $6 \mathrm{~b}$ ) and is replaced by altaite $(\mathrm{PbTe})$, bismuthinite $\left(\mathrm{Bi}_{2} \mathrm{~S}_{3}\right)$, bismite $\left(\mathrm{Bi}_{2} \mathrm{O}_{3}\right)$ and bismutite- $(\mathrm{BiO})_{2} \mathrm{CO}_{3}$. Also, bismuth typically occurs as aggregates when löllingite $\left(\mathrm{FeAs}_{2}\right)$ is replaced by arsenopyrite (FeAsS) (Figure 6a). It sometimes contains hessite and electrum microinclusions and forms microscopic intergrowths with acanthite $\left(\mathrm{AgS}_{2}\right)$. Bismuth aggregates dominantly display an anhedral morphology; some micronsized grains are rounded, drop-like. Supergene alteration led to the oxidation of native bismuth to bismite and bismutite.

Bismuthinite is much less abundant in PMD ores than native bismuth, which it replaces. It occurs in aposkarn greisens as microscopic intergrowths with fluorite (Figure 6d). In propylitized skarns it mainly forms microveinlets (Figure 6e). Bismuthinite commonly 
contains $\mathrm{Pb}$ and $\mathrm{Cu}$ (Table 3). These elements likely are forming substitution $\mathrm{Pb}^{2+}+\mathrm{Cu}^{+}$ $\leftrightarrow \mathrm{Bi}^{3+}+\nabla$ (aikinite-type of substitution).
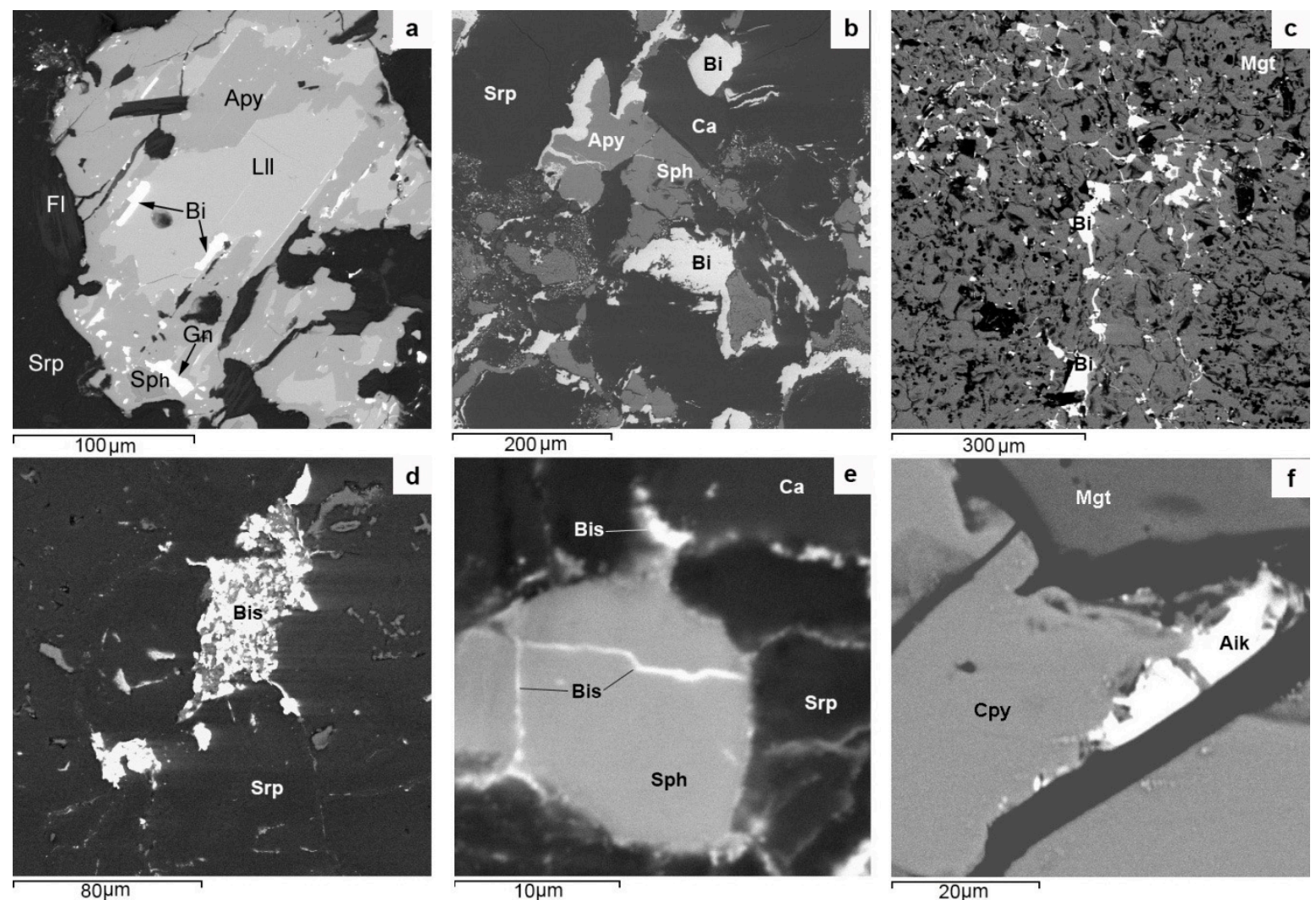

Figure 6. BSE images. Typical forms of native bismuth (Bi), bismuthinite (Bis) and aikinite (Aik)—(PbCuBiS3) aggregates in PMD ores; for the explanation, see text. Apy—arsenopyrite, $\mathrm{Ca} —$ calcite, Fl—phlogopite, Lll—löllingite. For explanation, see text.

Table 3. Representative electron microanalyses and atomic proportions of aikinite (1-3), bismuthinite (4-6), gladite- $\mathrm{CuPbBi}_{5} \mathrm{~S}_{9}$ (7), and emplectite- $-\mathrm{CuBiS}_{2}(8,9)$.

\begin{tabular}{|c|c|c|c|c|c|c|c|c|c|}
\hline wt.\% & 1 & 2 & 3 & 4 & 5 & 6 & 7 & 8 & 9 \\
\hline $\mathrm{Bi}$ & 38.69 & 31.87 & 32.68 & 73.06 & 79.18 & 78.96 & 65.20 & 54.64 & 55.14 \\
\hline $\mathrm{Pb}$ & 39.43 & 46.66 & 50.51 & 9.12 & $\mathrm{bd}$ & bd & 11.62 & 7.01 & 7.32 \\
\hline $\mathrm{Cu}$ & 16.54 & 12.63 & 11.97 & $\mathrm{bd}$ & 2.95 & $\mathrm{bd}$ & 4.14 & 19.27 & 18.77 \\
\hline $\mathrm{Fe}$ & 1.06 & 3.12 & $\mathrm{bd}$ & $\mathrm{bd}$ & $\mathrm{bd}$ & $\mathrm{bd}$ & bd & $\mathrm{bd}$ & $\mathrm{bd}$ \\
\hline S & 3.06 & 3.01 & 3.17 & 17.13 & 17.86 & 20.21 & 17.49 & 17.89 & 17.87 \\
\hline Total & 98.78 & 97.29 & 98.33 & 99.31 & 99.99 & 99.17 & 98.45 & 98.81 & 99.10 \\
\hline \multicolumn{10}{|c|}{ Chemical formula } \\
\hline $\mathrm{Bi}$ & 3.44 & 2.90 & 3.34 & 7.52 & 7.53 & 8.00 & 6.69 & 0.87 & 0.88 \\
\hline $\mathrm{Pb}$ & 3.55 & 4.29 & 5.21 & 0.92 & & & 1.21 & 0.12 & 0.12 \\
\hline $\mathrm{Cu}$ & 4.84 & 3.67 & 4.06 & & 0.94 & & 1.40 & 1.01 & 1.00 \\
\hline $\mathrm{Fe}$ & 0.37 & 1.06 & & & & & & & \\
\hline$S$ & 11.69 & 12.07 & 12.34 & 12.20 & 11.77 & 12.00 & 11.95 & 1.93 & 1.94 \\
\hline $\mathrm{n}_{\mathrm{aik}}$ & 101.57 & 119.33 & 112.41 & 1.85 & 0 & 0 & 30.63 & & \\
\hline
\end{tabular}

1-3, 8, 9-Kitilä; 4, 6-Herberz-1; 5, 7-Lupikko; bd-below detection limit. 1-3-probably mixed with chalcopyrite; 8, 9-probably mixed with galena. Formula of the aikinite, bismuthinite and gladite based on $(\mathrm{Cu}+\mathrm{Pb}) / 2+\mathrm{Bi}=8$, for emplectite based on sum cations 3 ; $\mathrm{n}_{\mathrm{aik}}=$ $2 \mathrm{~Pb} /(\mathrm{Pb}+\mathrm{Bi}) \times 100$.

Aikinite occurs in Kitelä ores as isometric inclusions in chalcopyrite and, together with chlorite, fills fractures in it (Figure 6f). Its composition differs from stoichiometric in the presence of $\mathrm{Fe}$ and variations in $\mathrm{Cu}, \mathrm{Pb}$ and $\mathrm{Bi}$ (Table 3). 
Gladite occurs as single xenomorphic grains, up to $30 \mu \mathrm{m}$ in size, in pyrrhotite from Lypikko ores. Some gladite grains contain native bismuth micron-sized inclusions and are overgrown by zavaritskite $(\mathrm{BiO}) \mathrm{F}$ film. Associated with gladite are pyrrhotite, pyrite, chalcopyrite, löllingite, stützite, scheelite, and fluorite. Gladite exhibits a near-stoichiometric composition (Table 3).

Emplectite is present as reticulate aggregates of fine elongate prismatic crystals in sphalerite (Figure 7c) and is encountered in Kitelä skarns. Scarce micron-sized (1-2 $\mu \mathrm{m})$ anhedral emplectite grains have also been found in the chalcopyrite of Arsenic Shaft ore skarns. Associated with emplectite are wittichenite, galena, and chalcopyrite. Emplectite contains $\mathrm{Pb}$ impurity (Table 3).
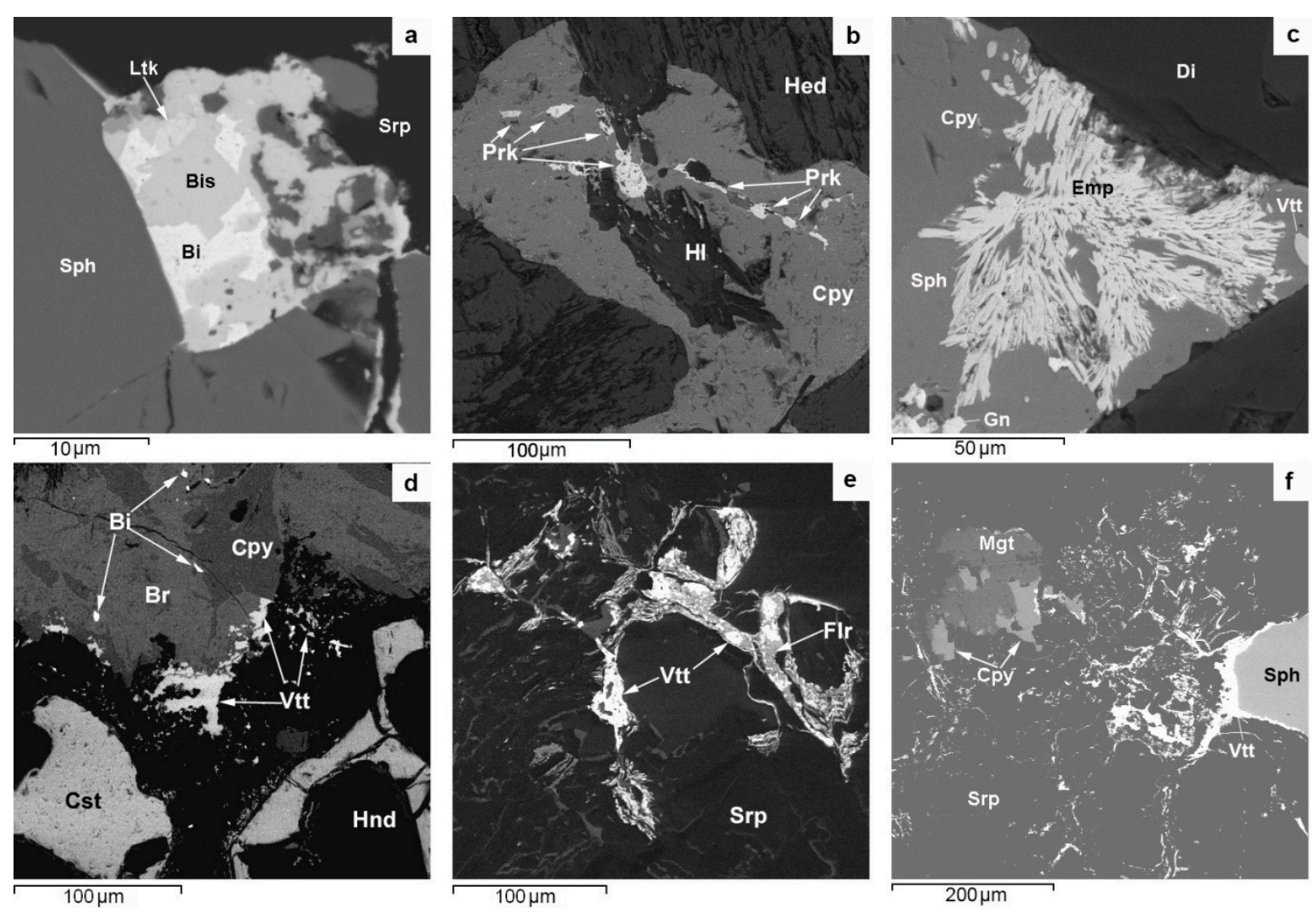

Figure 7. BSE images. Native bismuth (Bi), bismuthine (Bis), laitakarite - $\mathrm{Bi}_{4}(\mathrm{Se}, \mathrm{S})_{3}$ (Ltk), parkerite $-\mathrm{Bi}_{2} \mathrm{Ni}_{3} \mathrm{~S}_{2}(\operatorname{Prk})$, emplectite (Emp), wittechenite (Vtt) in Pitkäranta skarn ores; for the explanation, see text. Cst—cassiterite, Di-diopside, Hnd-chondrodite, Hed-hedenbergite, Hl—chlorite. For moredetail, see text.

Wittichenite $\left(\mathrm{Cu}_{3} \mathrm{BiS}_{3}\right)$ is the most common (after native bismuth) bismuth mineral in PMD skarns. It commonly forms, together with (Figure 7e) or without fluorite (Figure 7f), branching microveinlets and fine dust-like grains in serpentine matrix containing scarce magnetite, sphalerite, chalcopyrite, and cassiterite aggregates. Wittichenite occasionally rims chalcopyrite, bornite, sphalerite, and löllingite grains. Away from them, it seems to scatter as dust-like aggregate in serpentine (Figure $7 \mathrm{~d}, \mathrm{f})$. It often occurs in sphalerite as isometric aggregates together with fluorite, goethite, bismite, and hessite- $\left(\mathrm{Ag}_{2} \mathrm{Te}\right)$ (Hopunvaara). In propylitized magnesian skarns at the Kitilä deposit wittichenite, together with chalcopyrite and sphalerite, fills interstices between octahedral magnetite crystals. Here, it often occurs together with bornite as angular aggregates, up to $30-40 \mu \mathrm{m}$ in size, in chalcopyrite.

The chemical composition of wittichenite differs from stoichiometric in a small deficiency of sulfur and the presence of Fe and $\mathrm{Zn}$ in several analyses (Table 4). 
The minerals of the system $\mathrm{Bi}( \pm \mathrm{Pb})-\mathrm{Se}$, $\mathrm{S}$-Te are less common bismuth minerals than those described above. All of them, except for Se-galena, display micron sized aggregates $(<10 \mu \mathrm{m})$, often occurring as intergrowths. Therefore, their chemical composition is hard to analyze correctly. Se-galena commonly contains Ag (up to 6\%) and Te (up to 4\%) (Table 5).

Table 4. Representative electron microanalyses and atomic proportions of wittichenite.

\begin{tabular}{ccccccccccccc}
\hline wt. $\%$ & $\mathbf{1}$ & $\mathbf{2}$ & $\mathbf{3}$ & $\mathbf{4}$ & $\mathbf{5}$ & $\mathbf{6}$ & $\mathbf{7}$ & $\mathbf{8}$ & $\mathbf{9}$ & $\mathbf{1 0}$ & $\mathbf{1 1}$ \\
\hline $\mathrm{Bi}$ & 39.93 & 40.14 & 37.22 & 39.80 & 39.31 & 40.21 & 39.92 & 39.07 & 37.52 & 39.26 & 41.51 \\
$\mathrm{Zn}$ & $\mathrm{bd}$ & 1.61 & $\mathrm{bd}$ & $\mathrm{bd}$ & $\mathrm{bd}$ & $\mathrm{bd}$ & 2.98 & $\mathrm{bd}$ & $\mathrm{bd}$ & $\mathrm{bd}$ & $\mathrm{bd}$ \\
$\mathrm{Cu}$ & 38.89 & 37.24 & 42.28 & 36.87 & 39.12 & 39.84 & 35.72 & 39.56 & 40.01 & 38.99 & 38.87 \\
$\mathrm{Fe}$ & $\mathrm{bd}$ & $\mathrm{bd}$ & $\mathrm{bd}$ & 3.51 & $\mathrm{bd}$ & $\mathrm{bd}$ & $\mathrm{bd}$ & 1.03 & 2.18 & 1.92 & $\mathrm{bd}$ \\
$\mathrm{S}$ & 20.05 & 20.23 & 20.76 & 18.73 & 20.36 & 20.00 & 20.12 & 19.63 & 19.88 & 19.81 & 19.82 \\
Total & 98.87 & 99.22 & 100.26 & 98.91 & 98.79 & 100.05 & 98.74 & 99.29 & 99.59 & 99.98 & 100.20 \\
\hline & & & & & Chemical formula & & & & \\
\hline $\mathrm{Bi}$ & 0.96 & 0.99 & 0.85 & 0.98 & 0.93 & 0.95 & 1.02 & 0.93 & 0.89 & 0.94 & 0.98 \\
$\mathrm{Cu}$ & 3.04 & 3.01 & 3.15 & 3.02 & 3.07 & 3.05 & 2.98 & 3.07 & 3.11 & 3.06 & 3.02 \\
$\mathrm{~S}$ & 2.96 & 2.99 & 2.85 & 2.98 & 2.93 & 2.95 & 3.02 & 2.93 & 2.89 & 2.94 & 2.98 \\
\hline
\end{tabular}

1-2-Hopunvaara; 3-7-Arsenic Shaft; 8-11-Kitilä; bd—below the detection limit. Fe and $\mathrm{Zn}$ in the analyses are probable impurities; Formula of the wittichenite phase based on sum cations 4 .

Table 5. Representative electron microprobe analyses and atomic proportions of Se-galena (1), laitakarite $(2,3)$, rucklidgeitelike phase $(\mathrm{Pb}, \mathrm{Bi})_{3} \mathrm{Te}_{4}(4,5)$, hedleyite- $-\mathrm{Bi}_{7} \mathrm{Te}_{3}(6,7)$, and parkerite $(8-11)$.

\begin{tabular}{|c|c|c|c|c|c|c|c|c|c|c|c|}
\hline wt.\% & 1 & 2 & 3 & 4 & 5 & 6 & 7 & 8 & 9 & 10 & 11 \\
\hline $\mathrm{Bi}$ & & 77.55 & 79.30 & 34.81 & 46.68 & 77.79 & 81.25 & 62.78 & 60.00 & 58.19 & 60.53 \\
\hline $\mathrm{Pb}$ & 79.35 & 3.25 & 2.97 & 19.16 & 22.53 & bd & $\mathrm{bd}$ & $\mathrm{bd}$ & $\mathrm{bd}$ & 4.79 & $\mathrm{bd}$ \\
\hline $\mathrm{Ag}$ & $\mathrm{bd}$ & 0.83 & 0.83 & $\mathrm{bd}$ & $\mathrm{bd}$ & $\mathrm{bd}$ & $\mathrm{bd}$ & $\mathrm{bd}$ & 1.16 & $\mathrm{bd}$ & $\mathrm{bd}$ \\
\hline $\mathrm{Ni}$ & $\mathrm{bd}$ & $\mathrm{bd}$ & $\mathrm{bd}$ & $\mathrm{bd}$ & $\mathrm{bd}$ & $\mathrm{bd}$ & $\mathrm{bd}$ & 28.40 & 25.74 & 25.57 & 26.86 \\
\hline $\mathrm{Fe}$ & $\mathrm{bd}$ & $\mathrm{bd}$ & $\mathrm{bd}$ & bd & bd & bd & $\mathrm{bd}$ & bd & 2.20 & 1.98 & $\mathrm{bd}$ \\
\hline $\mathrm{Te}$ & bd & 1.50 & 1.54 & 45.80 & 27.00 & 21.43 & 17.79 & $\mathrm{bd}$ & $\mathrm{bd}$ & $\mathrm{bd}$ & $\mathrm{bd}$ \\
\hline Se & 14.51 & 12.62 & 12.59 & $\mathrm{bd}$ & $\mathrm{bd}$ & bd & $\mathrm{bd}$ & bd & $\mathrm{bd}$ & bd & $\mathrm{bd}$ \\
\hline$S$ & 5.37 & 3.57 & 3.92 & $\mathrm{bd}$ & $\mathrm{bd}$ & bd & $\mathrm{bd}$ & 9.78 & 9.71 & 8.60 & 9.71 \\
\hline Total & 99.40 & 99.32 & 101.15 & 99.77 & 96.21 & 99.22 & 99.04 & 100.96 & 98.81 & 99.13 & 98.80 \\
\hline \multicolumn{12}{|c|}{ Chemical formula } \\
\hline $\mathrm{Bi}$ & & 3.84 & 3.82 & 1.89 & 2.88 & 6.90 & 7.40 & 1.92 & 1.85 & 1.80 & 1.94 \\
\hline $\mathrm{Pb}$ & 1.04 & 0.16 & 0.15 & 1.05 & 1.40 & & & & & 0.15 & \\
\hline $\mathrm{Ag}$ & & 0.08 & 0.08 & & & & & & 0.07 & & \\
\hline $\mathrm{Ni}$ & & & & & & & & 3.08 & 2.83 & 2.82 & 3.06 \\
\hline $\mathrm{Fe}$ & & & & & & & & & 0.25 & 0.23 & \\
\hline $\mathrm{Te}$ & & 0.12 & 0.12 & 4.06 & 2.72 & 3.10 & 2.60 & & & & \\
\hline Se & 0.50 & 1.65 & 1.61 & & & & & & & & \\
\hline $\mathrm{S}$ & 0.46 & 1.15 & 1.23 & & & & & 1.95 & 1.95 & 1.74 & 2.03 \\
\hline
\end{tabular}

1, 4-10-Lupikko, 2, 3-Herberz-1, 11-Herberz-2; in an. 11 determined by U-1.7\%; bd-below detection limit. Formula of the Se-galena based on sum of 2 atoms, for laitakarite phase based on sum 7 atoms, for rucklidgeite based on sum 7 atoms, for hedleyite based on sum 10 atoms, for parkerite based on sum cations 5 .

Some of the minerals in this system (ikunolite, aleksite, tetradymite, and joseite-B) occur in micron-sized aggregates but very seldom. Their compositions, obtained by several analyses, were quite correct, hence their position in the diagram $(\mathrm{Bi}+\mathrm{Pb})-(\mathrm{Se}+\mathrm{S})-\mathrm{Te}$ (Figure 8).

Laitakarite was identified in skarns from Herberz-2 mine. It occurs as micron-sized inclusions in native bismuth (Figure 7a). Laitakarite always contains $\mathrm{Pb}$ and $\mathrm{Ag}$ (Table 5). Some of our analyses show that its composition is similar in Se-S ratio to that of ikunolite (Figure 8).

Rucklidgeite is encountered in Lupikko and Arsenic Shaft ores. It is associated with native bismuth, altaite, Au-bearing silver, and a mineral similar in composition to joseite-B and 
sulfotsumoite. The composition of rucklidgeite seems to vary considerably (Table 5, Figure 8), unless it is the result of an analytical error caused by the micron size of its aggregates.

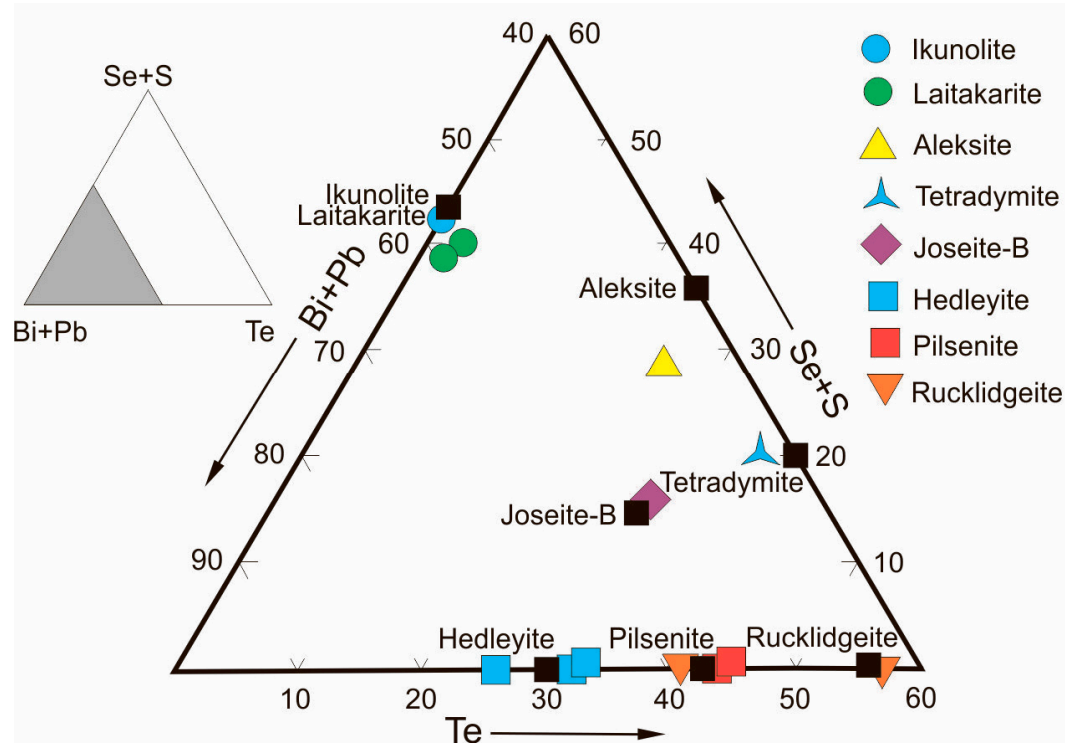

Figure 8. Ternary $(\mathrm{Bi}+\mathrm{Pb})-(\mathrm{Se}+\mathrm{S})$-Te plot showing bismuth minerals of interest in this study.

Hedleyite in ore skarns forms fine $(\sim 1 \mu \mathrm{m})$ discontinuous rims around ball-shaped native bismuth aggregates and coarser (up to $10 \mu \mathrm{m}$ ) aggregates in it which adjoin its external boundary. This association is occasionally joined by idiomorphic gahnite inclusions in bismuth rimmed by zavaritskite films. Hedleyite in aposkarn greisens occurs dominantly as aggregates of xenomorphic grains, up to $40-50 \mu \mathrm{m}$ in size. It is occasionally encountered as inclusions in sphalerite. The composition of hedleyite is near-stoichiometric (Table 5), but occasionally deviates towards tsumoite (Figure 8). In this case, it is enriched in Ag (up to $2 \%$ ).

Parkerite is a rare mineral. It occurs mainly in sulphide-nickel ores. It is not characteristic of skarns with $\mathrm{Cu}-\mathrm{Zn}-\mathrm{Sn}$-Be mineralization. It has been identified in partly chloritized hedenbergite skarns from the Lupikko deposit and in greisenized amphibole-pyroxenegarnet skarns from Herberz-2 mine. In Lupikko ores, it forms chains of fine (up to $30 \mu \mathrm{m}$ ) grains in chalcopyrite (Figure $7 \mathrm{~b}$ ) and in Herberz-2 skarns it occurs as complex intergrowths (up to $100 \mu \mathrm{m}$ ) with galena, native silver, and acanthite in chalcopyrite. Parkerite of both associations exhibits an almost perfect chemical composition (Table 5).

A group of Ag-bearing bismuth sulfosalts in PMD ores consists of the minerals of the $\mathrm{Ag}-\mathrm{Cu}-\mathrm{Bi}( \pm \mathrm{Pb})-\mathrm{S}$ system. Most minerals in this system, except for matildite, display a very limited distribution, but they all are preferably present in copper-base metal ores, where chalcopyrite is the dominant ore mineral.

Angelaite $\left(\mathrm{Cu}_{2} \mathrm{AgPbBiS}_{4}\right)$ occurs as clusters of anhedral grains, up to $100 \mu \mathrm{m}$ in size, in proselytized skarns from the Kitelä deposit (Figure 9a) and discontinuous micron-sized $(1-10 \mu \mathrm{m})$ rims on sphalerite grains in Arsenic Shaft ores (Figure 9b). Its composition differs from in low to zero $\mathrm{Pb}$ concentration from the stoichiometric composition (Table 6).

Arcubisite was identified in Kitilä copper ores. Its inclusions in chalcopyrite are up to $40 \mu \mathrm{m}$ in size (Figure 9c). Arcubisite occurs there in micron-sized intergrowths with galena and cervelleite, therefore, its most representative analysis showed the shortage of $S$ and the presence of Te (Table 6).

Argentian wittite forms fine $(10-15 \mu \mathrm{m})$ lozenge inclusions in chalcopyrite from Lupikko hedenbergite skarns (Figure 9f). It is associated with parkerite, hessite and nickeline. The composition of argentian wittite differs in elevated $\mathrm{Pb}$ and $\mathrm{Ag}$ and low $\mathrm{S}$ and Se concentrations from stoichiometric composition (Table 6). 

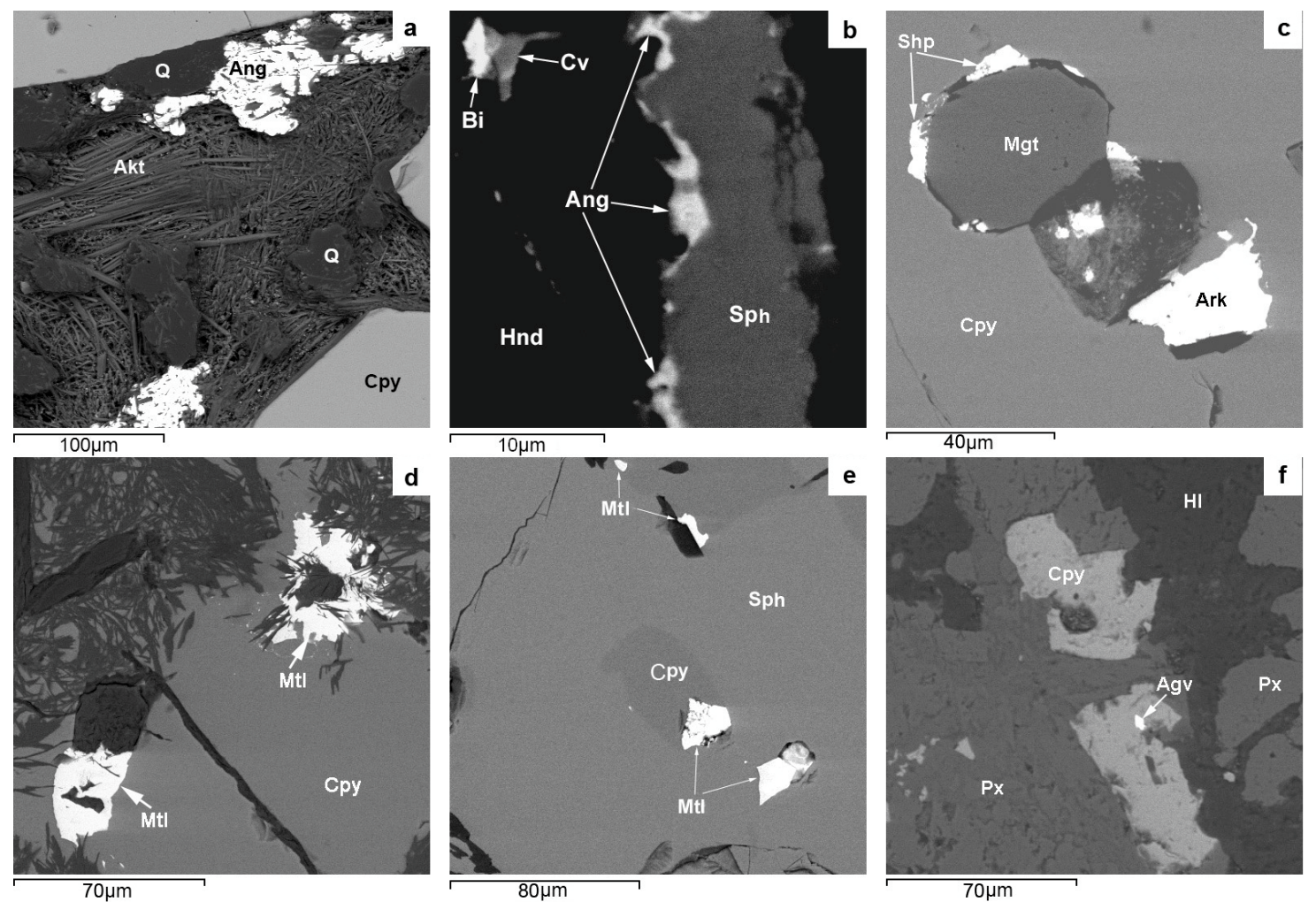

Figure 9. BSE images. Angelaite (Ang), arcubisite- $\mathrm{Ag}_{6} \mathrm{CuBiS}_{4}$ (Ark), "schapbachite” $-\mathrm{Ag}_{0} \cdot 4 \mathrm{~Pb}_{0 \cdot 2} \mathrm{Bi}_{0} \cdot 4 \mathrm{~S}$ (Shp), matildite$\mathrm{AgBiS}_{2}(\mathrm{Mtl})$, and argentowittite- $(\mathrm{Pb}, \mathrm{Ag})_{9} \mathrm{Bi}_{12}(\mathrm{~S}, \mathrm{Se})_{27}(\mathrm{Agv})$ in PMD skarn ores; for the explanation, see text. Aktactinolite, $\mathrm{Cv}$-covellite, $\mathrm{Px}$ - pyroxene. For more detail, see text.

Table 6. Representative electron microanalyses and atomic proportions of argentian wittite-like phase $(1,2)$. angelaite-like phase (3-5), arcubisite-like phase (6), "schapbachite" (7), pavonite- $(\mathrm{Ag}, \mathrm{Cu})(\mathrm{Bi}, \mathrm{Pb})_{3} \mathrm{~S}_{5}(8)$.

\begin{tabular}{|c|c|c|c|c|c|c|c|c|}
\hline wt. $\%$ & 1 & 2 & 3 & 4 & 5 & 6 & 7 & 8 \\
\hline $\mathrm{Bi}$ & 34.55 & 27.89 & 32.10 & 31.65 & 33.12 & 13.75 & 44.26 & 65.65 \\
\hline $\mathrm{Pb}$ & 26.38 & 40.87 & 6.33 & 3.50 & 6.72 & bd & 19.51 & 7.32 \\
\hline $\mathrm{Te}$ & bd & bd & bd & bd & bd & 11.47 & bd & $\mathrm{bd}$ \\
\hline $\mathrm{Ag}$ & 19.44 & 13.97 & 22.88 & 26.12 & 22.08 & 57.51 & 20.82 & 7.61 \\
\hline Se & 6.17 & 5.67 & bd & bd & bd & bd & bd & $\mathrm{bd}$ \\
\hline $\mathrm{Cu}$ & $\mathrm{bd}$ & $\mathrm{bd}$ & 18.69 & 18.18 & 18.90 & 5.43 & $b d$ & 1.25 \\
\hline $\mathrm{Fe}$ & bd & bd & bd & bd & bd & 0.81 & bd & $\mathrm{bd}$ \\
\hline $\mathrm{S}$ & 11.65 & 10.50 & 18.87 & 19.68 & 18.19 & 9.99 & 14.49 & 17.06 \\
\hline Total & 98.19 & 98.90 & 98.87 & 99.13 & 99.01 & 98.96 & 99.08 & 98.89 \\
\hline \multicolumn{9}{|c|}{ Chemical formula } \\
\hline $\mathrm{Bi}$ & 7.34 & 6.08 & 1.11 & 1.16 & 1.14 & 0.76 & 0.42 & 2.86 \\
\hline $\mathrm{Pb}$ & 5.66 & 9.01 & 0.22 & 0.13 & 0.23 & & 0.19 & 0.32 \\
\hline $\mathrm{Te}$ & & & & & & 1.02 & & \\
\hline $\mathrm{Ag}$ & 8.00 & 5.91 & 1.54 & 1.69 & 1.48 & 6.09 & 0.39 & 0.64 \\
\hline Se & 3.71 & 3.79 & & & & & & \\
\hline $\mathrm{Cu}$ & & & 2.13 & 2.02 & 2.15 & 0.98 & & 0.18 \\
\hline $\mathrm{Fe}$ & & & & & & 0.17 & & \\
\hline$S$ & 16.96 & 17.28 & 3.72 & 3.73 & 3.76 & 3.82 & 1.02 & 5.02 \\
\hline
\end{tabular}

1, 2-Lupikko; 3,4-Arsenic Shaft; 5-7-Kitilä; 8-Hopunvaara; bd-below detection limit. Formula of the argentian wittite-like phase based on sum cations 21 , for angelaite-like phase based on sum cations 5 , for arcubisite-like phase based on sum cations 8 , for "schapbachite" based on sum cations 1 , for pavonite based on sum cations 4 .

Pavonite occurs as tabular grains and lamellae in chalcopyrite and fine intergrowths with joseite-B and hessite in Hopunvaara sphalerite [15]. Its composition differs slightly 
in higher Bi concentration from a perfect one (Table 6). Hopunvaara sphalerite contains inclusions of a mineral similar in composition to "schapbachite" (Table 6).

Matildite is widespread in Klee-6 sphalerite-chalcopyrite ores and is not uncommon in propylitized skarns with $\mathrm{Fe}-\mathrm{Cu}-\mathrm{Sn}$ mineralization at the Kitelä deposit. At Klee-6 mine, its aggregates are typically shaped like subhexagonal or anhedral inclusions in chalcopyrite, which, in turn, is often present as inclusions in sphalerite (Figure 9d,e). At Kitelä, it occurs as micron-sized (up to $10 \mu \mathrm{m}$ ) aggregates in chalcopyrite, which often contains galena inclusions. The composition of matildite at these deposits differs mainly in $\mathrm{Pb}$ and $\mathrm{Se}$ concentrations (Table 7).

Table 7. Representative electron microanalyses and atomic proportions of matildite.

\begin{tabular}{|c|c|c|c|c|c|c|c|c|c|c|c|}
\hline wt. \% & 1 & 2 & 3 & 4 & 5 & 6 & 7 & 8 & 9 & 10 & 11 \\
\hline $\mathrm{Ag}$ & 31.45 & 28.48 & 29.13 & 28.70 & 29.67 & 29.20 & 28.31 & 28.36 & 28.83 & 28.15 & 25.54 \\
\hline $\mathrm{Te}$ & bd & bd & bd & bd & 1.72 & bd & bd & bd & bd & bd & bd \\
\hline $\mathrm{Cu}$ & $\mathrm{bd}$ & bd & $\mathrm{bd}$ & $\mathrm{bd}$ & $\mathrm{bd}$ & $\mathrm{bd}$ & $\mathrm{bd}$ & $\mathrm{bd}$ & 1.33 & $\mathrm{bd}$ & $\mathrm{bd}$ \\
\hline $\mathrm{Pb}$ & $\mathrm{bd}$ & $\mathrm{bd}$ & bd & bd & $\mathrm{bd}$ & 7.94 & $\mathrm{bd}$ & $\mathrm{bd}$ & 5.51 & 5.68 & 18.63 \\
\hline $\mathrm{Bi}$ & 52.03 & 53.20 & 52.63 & 52.91 & 52.43 & 48.49 & 53.60 & 53.86 & 47.57 & 46.88 & 36.88 \\
\hline Se & $\mathrm{bd}$ & bd & $\mathrm{bd}$ & bd & bd & bd & bd & bd & $\mathrm{bd}$ & 3.71 & 1.99 \\
\hline $\mathrm{S}$ & 16.51 & 17.46 & 17.26 & 17.19 & 16.72 & 15.23 & 16.79 & 17.01 & 15.52 & 14.74 & 15.83 \\
\hline Total & 99.99 & 99.14 & 99.02 & 98.80 & 100.54 & 100.86 & 98.70 & 99.23 & 98.76 & 99.16 & 98.87 \\
\hline \multicolumn{12}{|c|}{ Chemical formula } \\
\hline $\mathrm{Ag}$ & 1.07 & 1.02 & 1.04 & 1.02 & 1.05 & 1.01 & 1.01 & 1.01 & 0.99 & 1.01 & 0.95 \\
\hline $\mathrm{Te}$ & & & & & 0.05 & & & & & & \\
\hline $\mathrm{Cu}$ & & & & & & & & & 0.08 & & \\
\hline $\mathrm{Pb}$ & & & & & & 0.14 & & & 0.09 & 0.11 & 0.35 \\
\hline $\mathrm{Bi}$ & 0.93 & 0.98 & 0.96 & 0.98 & 0.95 & 0.85 & 0.99 & 0.99 & 0.84 & 0.88 & 0.70 \\
\hline Se & & & & & & & & & & 0.18 & 0.10 \\
\hline$S$ & 1.93 & 1.98 & 1.96 & 1.98 & 1.90 & 1.92 & 1.99 & 1.99 & 1.89 & 1.76 & 1.78 \\
\hline
\end{tabular}

1-9-Klee -6; 10-11—Kitilä; bd-below detection limit. Formula of the matildite based on sum cations 2.

The Ag-bearing bismuth sulfosalts of PMD ores generally display a fairly persistent composition without marked variations in major element concentrations (Figure 10). In the Ag-Bi-Cu diagram they form several compact groups (Figure 10). The persistence of their composition seems to be due to the relative stability of their physico-chemical crystallization conditions.

\subsection{Minerals of the System $A g$-Te-Se}

Hessite is most characteristic of the Lupikko deposit, but it is often present in ores from other PMD deposits. Its aggregates are typically shaped as subhexagonal grains measuring up to $70 \mu \mathrm{m}$ (Figure 11a), xenomorphic and veinlet-like units (Figure 11b), micron-sized films on chalcopyrite, stokesite (Figure 11c), pyrrhotite, sphalerite, etc. Hessite and locally stutzite are present as micron-sized inclusions in altaite (Figure 11f), chondrodite, fluorite (Figure 11b), chlorite, K-feldspar, hedenbergite, serpentine, and chalcopyrite. Hessite is often associated with native bismuth, galena, löllingite, and lesser hedleyite (Figure 11e). Euhedral $(30-40 \mu \mathrm{m})$ hessite aggregates in sphalerite and its fine grains along the sphaleritechalcopyrite boundary in association with stannoidite and bornite and joint intergrowths with fluorite in sphalerite (Arsenic Shaft) are less common. At the Kitelä deposit, hessite often occurs together with cassiterite, chalcopyrite, pyrite, and stokesite (Figure 11c). It varies in composition from pure varieties to selenium-bearing and intermediate phases of the isomorphic hessite-naumannite series (Table 8, Figure 12), although naumannite itself is extremely scarce (Arsenic Shaft). It forms xenomorphic micron-sized aggregates in covellite in aposkarn greisens with fluorite and magnetite (Figure 11d). 


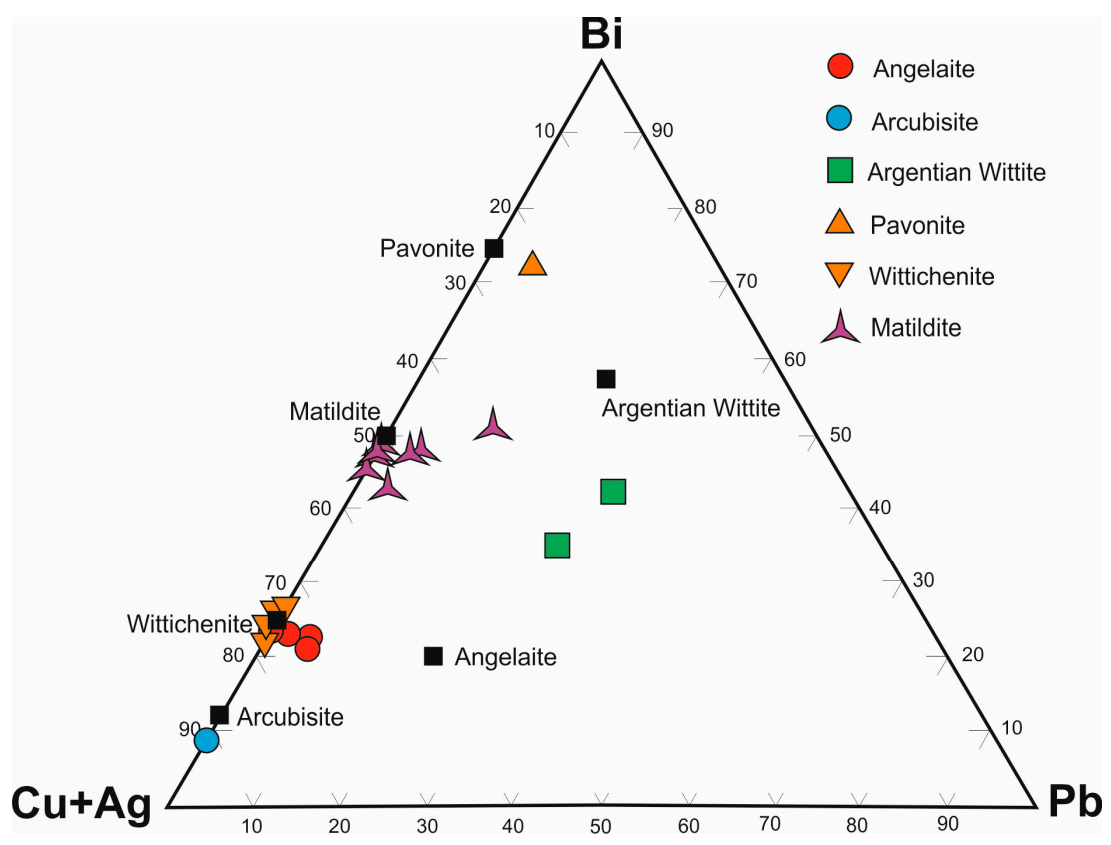

Figure 10. Ternary Ag-Bi-Cu plot showing the composition of Ag-Bi sulfosalts.
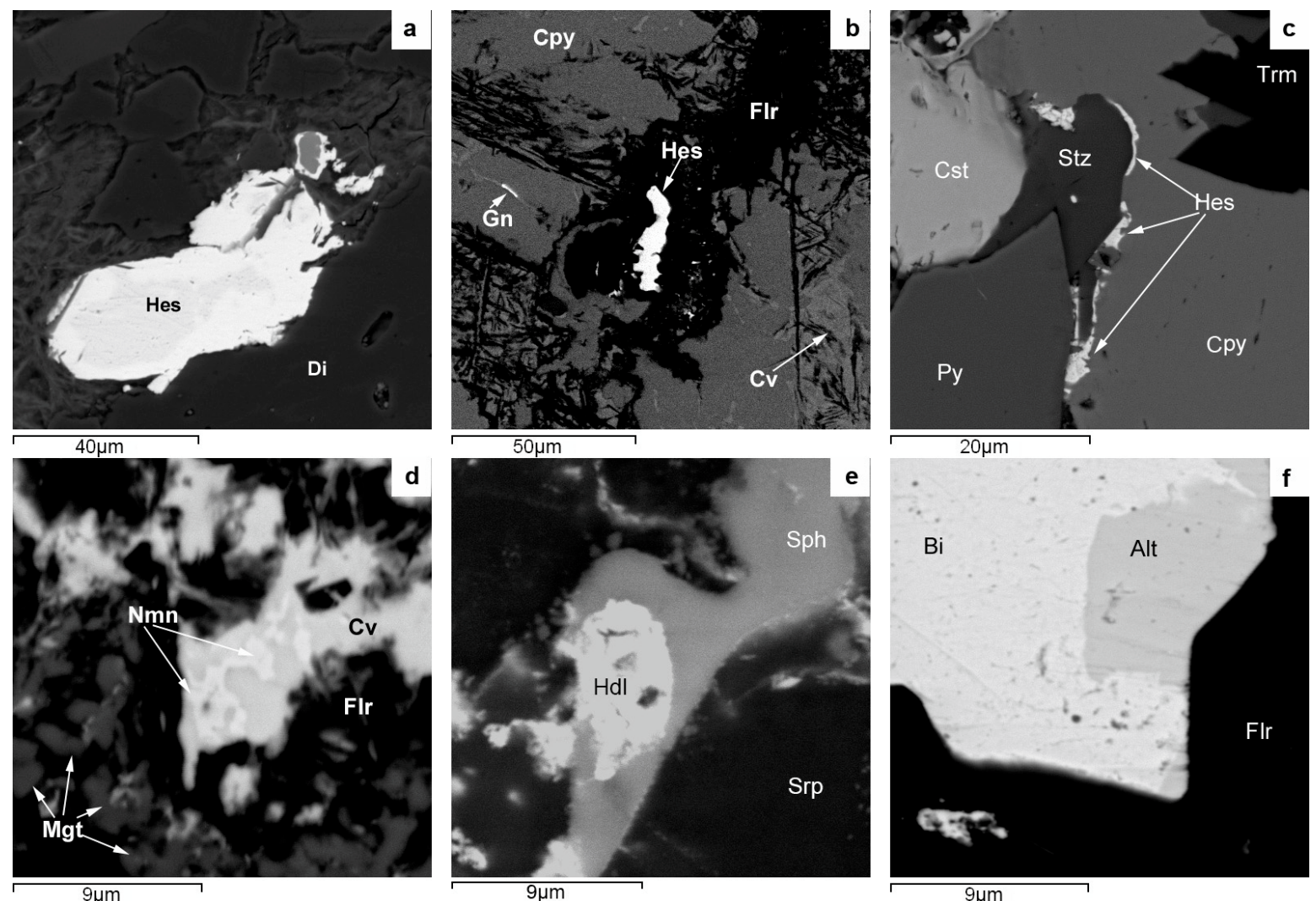

Figure 11. BSE images. Hessite (Hes) and naumannite- $\mathrm{Ag}_{2} \mathrm{Se}(\mathrm{Nmn})$ in PMD skarn ore; for the explanation, see text. Alt-altaite $(\mathrm{PbTe}), \mathrm{Cv}$-covellite, $\mathrm{Hdl}$-hedleyite, $\mathrm{Py}$ - pyrite, Stz-stokesite $\left(\mathrm{CaSnSi}_{3} \mathrm{O}_{9} \cdot 2\left(\mathrm{H}_{2} \mathrm{O}\right)\right)$, Trm-tremolite. For more detail, see text. 
Table 8. Representative electron microanalyses and atomic proportions of hessite $(1,2)$, hessite- naumannite solid solution (3-5), naumannite (6), stützite $(7,8)$ and kurilite (9) and cervelleite (10).

\begin{tabular}{|c|c|c|c|c|c|c|c|c|c|c|}
\hline wt. $\%$ & 1 & 2 & 3 & 4 & 5 & 6 & 7 & 8 & 9 & 10 \\
\hline $\mathrm{Te}$ & 37.43 & 38.06 & 22.83 & 28.32 & 35.22 & $b d$ & 43.04 & 41.29 & 23.83 & 21.35 \\
\hline $\mathrm{Au}$ & bd & bd & bd & bd & bd & bd & bd & bd & 11.44 & bd \\
\hline $\mathrm{Ag}$ & 61.81 & 62.03 & 65.28 & 63.67 & 61.36 & 73.37 & 56.82 & 58.44 & 60.05 & 69.34 \\
\hline $\mathrm{Cu}$ & bd & bd & bd & bd & $\mathrm{bd}$ & bd & bd & bd & bd & 2.03 \\
\hline Se & $\mathrm{bd}$ & $b d$ & 11.02 & 6.66 & 2.23 & 26.90 & $\mathrm{bd}$ & $\mathrm{bd}$ & $\mathrm{bd}$ & $\mathrm{bd}$ \\
\hline S & $\mathrm{bd}$ & bd & bd & 0.87 & $\mathrm{bd}$ & bd & bd & bd & 3.54 & 6.41 \\
\hline Total & 99.24 & 100.09 & 99.13 & 99.52 & 98.81 & 100.27 & 99.86 & 99.73 & 98.86 & 99.13 \\
\hline \multicolumn{11}{|c|}{ Chemical formula } \\
\hline $\mathrm{Te}$ & 1.00 & 1.00 & 0.56 & 0.67 & 0.91 & & 3.00 & 3.00 & 0.64 & 0.81 \\
\hline $\mathrm{Au}$ & & & & & & & & & 0.19 & \\
\hline $\mathrm{Ag}$ & 2.00 & 2.00 & 2.00 & 2.00 & 2.00 & 2.00 & 5.00 & 5.00 & 1.81 & 3.81 \\
\hline $\mathrm{Cu}$ & & & & & & & & & & 0.19 \\
\hline Se & & & 0.44 & 0.25 & 0.09 & 1.00 & & & & \\
\hline$S$ & & & & 0.08 & & & & & 0.36 & 1.19 \\
\hline
\end{tabular}

1, 6-Arsenic Shaft; 2-4, 7, 9-Lupikko; 5, 10-Kitilä; 8-Klee-6; bd-below detection limit. Formula of the hessite based on sum cations 2, for naumannite based on sum cations 2 , for stützite based on sum cations 5 , for kurilite based on sum cations 2 , for cervelleite based on sum cations 4 .

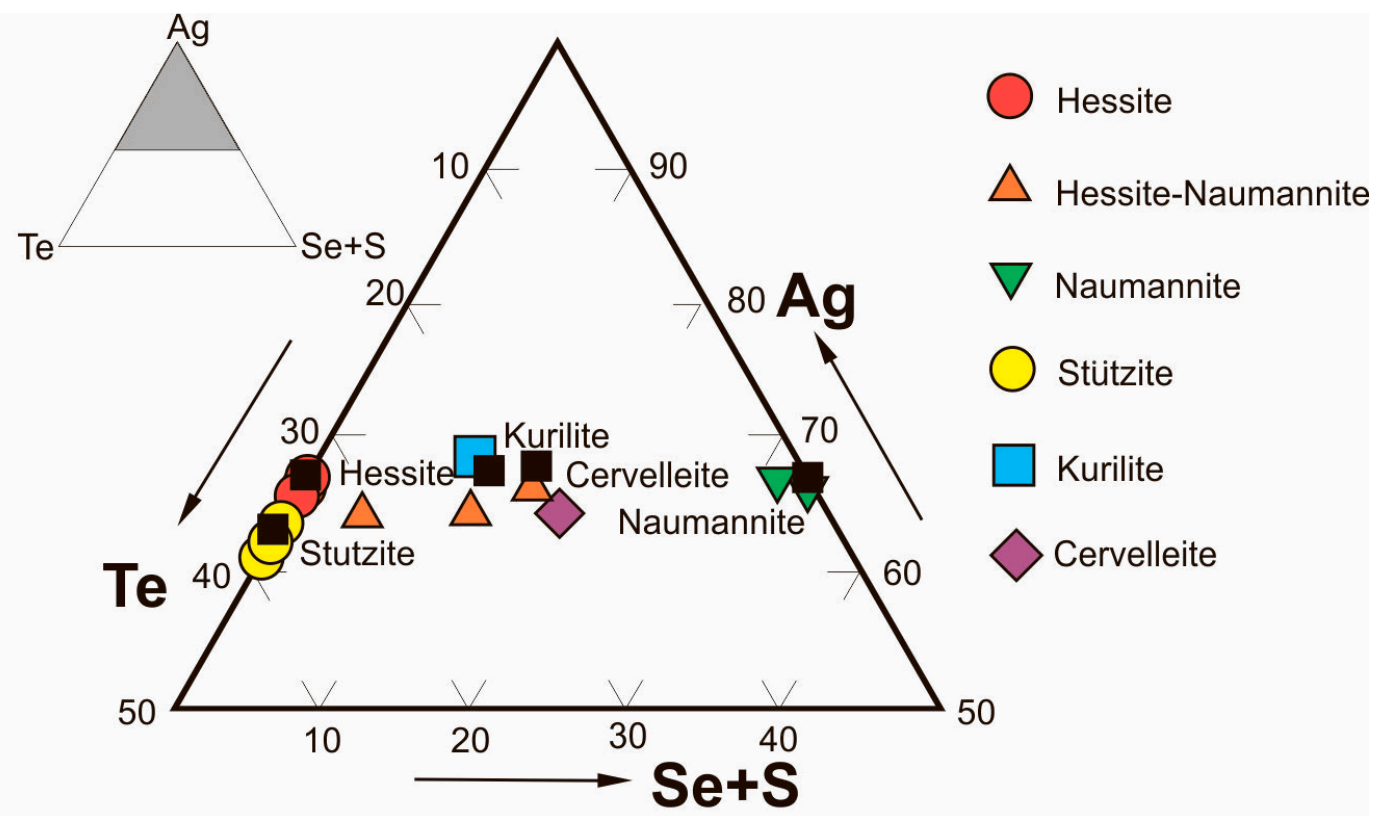

Figure 12. Ternary Te-Ag-Se plot showing the composition of Ag-tellurides and Ag-selenides.

Kurilite. The only micron-sized grain has been found as an inclusion in pyrrhotite from Lupikko ore. This mineral is easily estimated using the kurilite formula, but it contains no Se (Table 8).

\subsection{Beryllium Minerals}

Beryllium minerals occur only in aposkarn greisens and in isofacial metasomatic rocks formed after gneissose granite and granite. Beryllium mineralization is most diverse in Hopunvaara, Lupikko, Uuksa, and Ristiniemi aposkarn greisens, in which [10] over 10 mineral types of Be (helvite, danalite, phenakite, bertrandite, bromellite, beryl, chrysoberyl, taaffeite, behoite, berborite, bityite, herderite etc.) were identified. Helvite group minerals and danalite are most common. They occur as dark-brown, ruby-red, and pinkish tetrahedral and tabular crystals measuring up to $5 \mathrm{~cm}$ (Figure 13). These minerals 
are commonly associated with cassiterite, löllingite, and fluorite and are often replaced by phenacite, bromellite, and bertrandite.

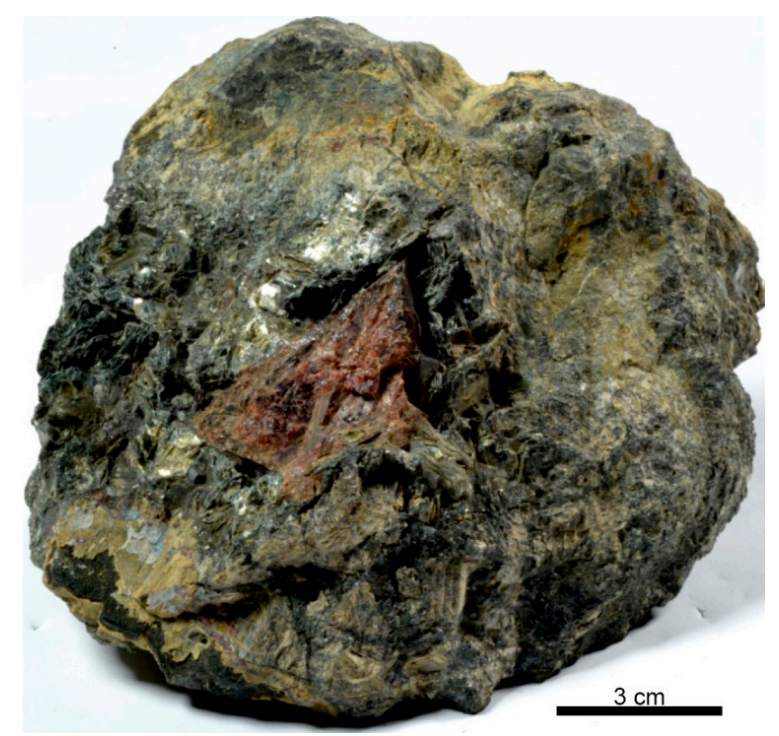

Figure 13. Brownish-red helvite- $\left(\mathrm{Mn}_{4}\left(\mathrm{Be}_{3} \mathrm{Si}_{3} \mathrm{O}_{12}\right) \mathrm{S}\right.$ crystal in aposkarn greisen with magnetite. Lupikko [52].

The composition of helvite is near-stoichiometric (Table 9). Danalite contains an excess of total $\mathrm{Mg}, \mathrm{Mn}, \mathrm{Fe}$, and $\mathrm{Zn}$ (Table 9). The increase of Fe concentration in helvite and danalite $-\mathrm{Fe}_{4}\left(\mathrm{Be}_{3} \mathrm{Si}_{3} \mathrm{O}_{12}\right) \mathrm{S}$ is paralleled by an increase in $\mathrm{Zn}$ concentration, showing the variability of this group of minerals upon a rise in their FE concentration towards genthelvite (Figure 14).

Table 9. Representative electron microanalyses and atomic proportions of helvite group minerals [53].

\begin{tabular}{cccc}
\hline wt. $\%$ & $\mathbf{1}$ & $\mathbf{2}$ & $\mathbf{3}$ \\
\hline $\mathrm{BeO}{ }^{*}$ & 11.30 & 9.81 & 8.48 \\
$\mathrm{MgO}$ & 0.02 & 0.08 & 0.48 \\
$\mathrm{ZnO}$ & 2.40 & 11.71 & 17.78 \\
$\mathrm{FeO}$ & 5.92 & 16.42 & 31.51 \\
$\mathrm{MnO}$ & 43.65 & 26.66 & 6.65 \\
$\mathrm{SiO}$ & 34.20 & 32.79 & 32.62 \\
$\mathrm{~S}$ & 5.02 & 5.07 & 4.95 \\
$-\mathrm{O}=\mathrm{S}$ & 2.51 & 2.53 & 2.48 \\
$\mathrm{Total}$ & 100.00 & 100.01 & 99.99 \\
& & & \\
$\mathrm{Be}$ & 2.54 & 2.28 & 2.01 \\
$\mathrm{Mg}$ & & 0.01 & 0.07 \\
$\mathrm{Zn}$ & 0.17 & 0.84 & 1.30 \\
$\mathrm{Fe}$ & 0.46 & 1.33 & 2.61 \\
$\mathrm{Mn}$ & 3.45 & 2.19 & 0.56 \\
$\mathrm{Si}$ & 3.19 & 3.18 & 3.23 \\
$\mathrm{~S}$ & 0.88 & 0.92 & 0.92 \\
\hline
\end{tabular}

*-calculated data. Formula of helvite group minerals were calculated by the oxygen method based on sum anions $=13$. 


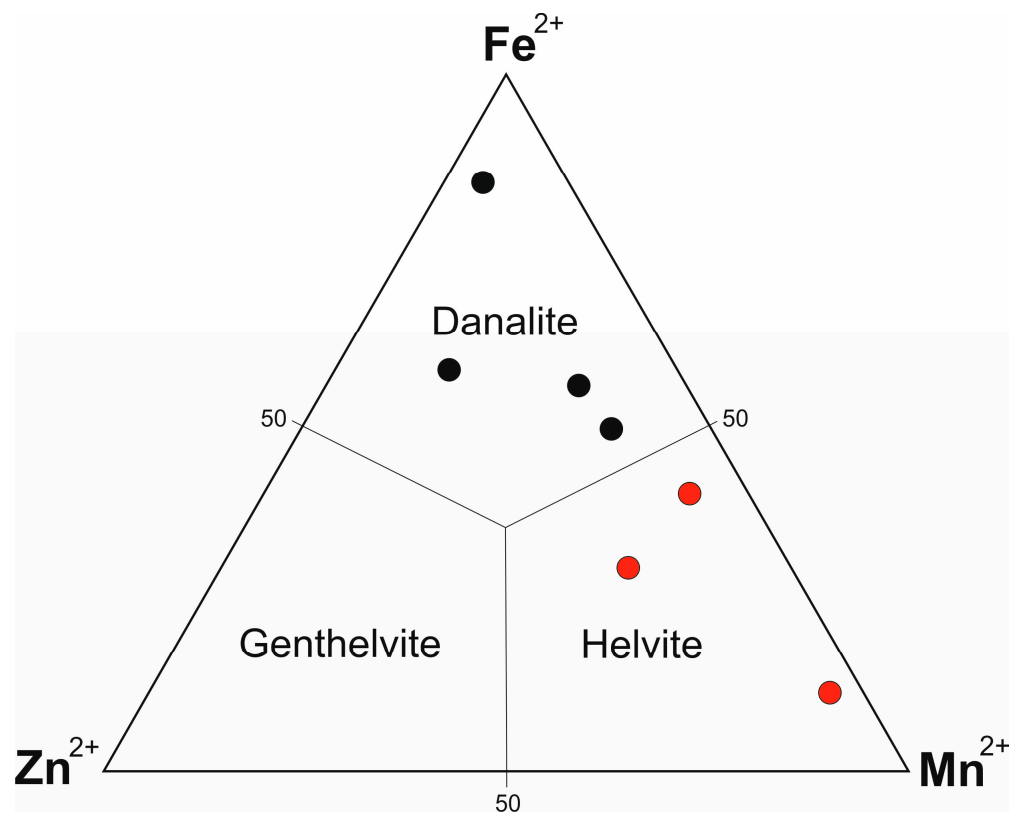

Figure 14. $\mathrm{Fe}^{2+}, \mathrm{Mn}^{2+}, \mathrm{Zn}^{2+}$ ratio in helvite group minerals. Lupikko [53].

\section{Discussion}

Examination of skarns PMD reveals the following paragenetic sequence of hydrothermal ore mineralization (Figure 15) which can be recognized based on mineralogical and structural relationships.

The magnesian-skarn stage is marked by the formation of a small number of ore minerals: magnetite, boron minerals, sphalerite, chalcopyrite. Magnetite, Sn-bearing garnet, cassiterite, sphalerite, and chalcopyrite crystallized during the formation of calcareous skarns. The stages of aposcarn greisens and propylitized skarns are marked by the richest ore mineralization. Be-containing vesuvian, helvine, danalite, chrysoberyl, and roquesite are the earliest rare metal minerals of these stages.

Minerals of $\mathrm{Bi}, \mathrm{Te}, \mathrm{Se}, \mathrm{Ag}$, and $\mathrm{Au}$ were formed mainly at the stage of propylitized skarns. Most of them are contained in skarns in trace amounts (Figure 15) and, as a result, their paragenetic ratios cannot be determined at this stage of research and this is to be done in the framework of future research. Some conclusions in this aspect can be drawn when comparing the rare metal mineralization in PMD skarns and other regions [54-58].

Rare-metal ( $\mathrm{In}, \mathrm{Bi}, \mathrm{Te}, \mathrm{Se}, \mathrm{Be})$ mineralization in the PMD is consistent in species diversity with that of skarn deposits, in which the cessation of ore formation was paralleled by the formation of low-temperature metasomatic rocks (propylites, serpentinites, etc.) with the well-defined ore-geochemical association Au-Bi-Pb-Sb-Ag-Te-As [54-57] and deposits with aposkarn metasomatic rocks such as fluorite-enriched greisens with Be [58]. This seems to be due to the long (17 million years) discrete (6 pulses) formation of the SARGB. Therefore, the physic-chemical parameters of mineralization at its exocontact are highly varied. This probably explains the crystallization of bismuth sulphosalts of nonstoichiometric composition, which is also noted in skarn deposits of other regions, for example, at the Stan Terg deposit in Kosovo (Romania) [54]. 


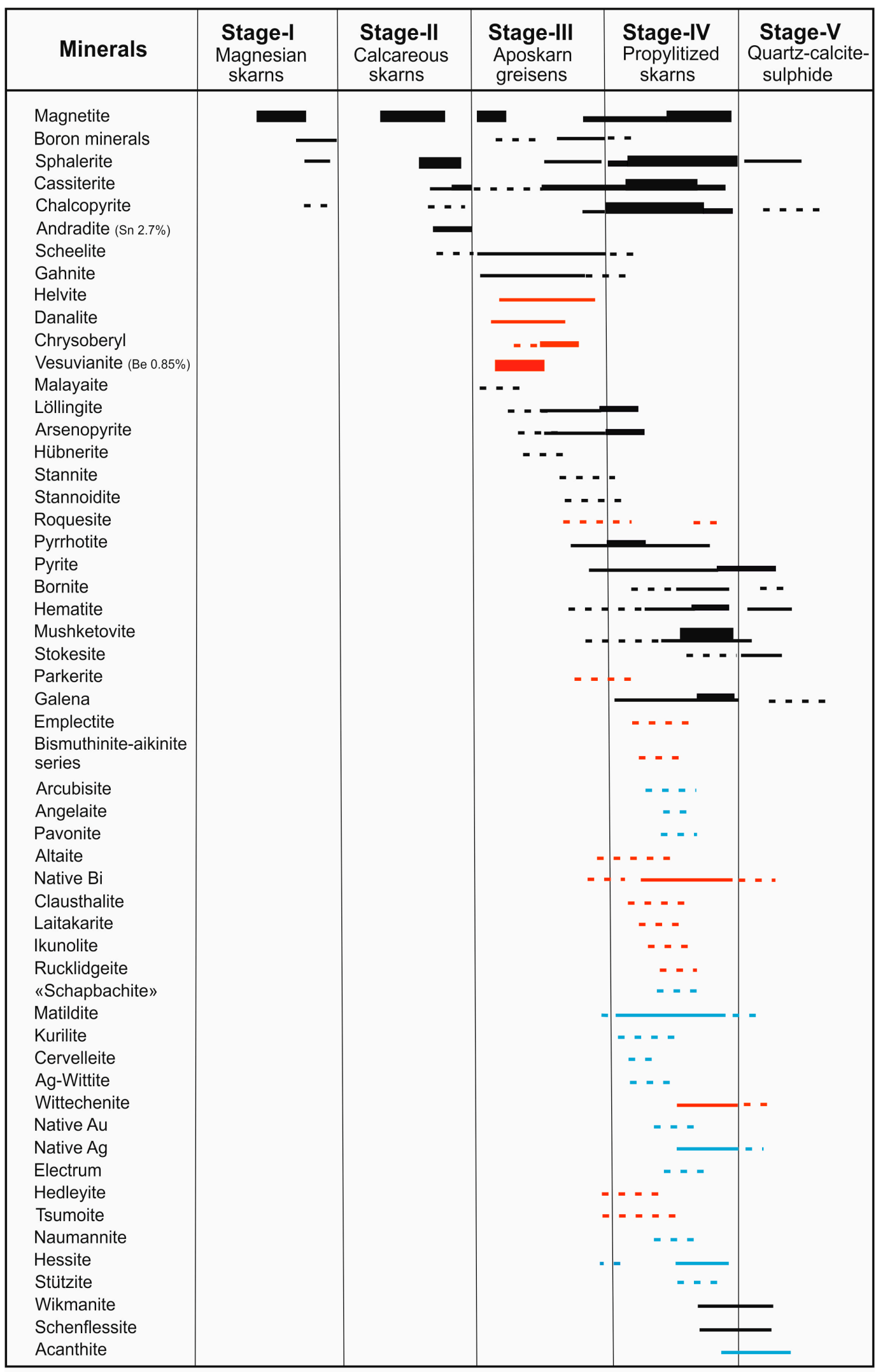

Acanthite

minor minerals - - - accessory minerals

Figure 15. Paragenetic sequence of ore mineralization from the PMD skarns; minerals of ferrous and base metals (black), minerals of rare metals (red), minerals of precious metals (blue). 
The cobaltite thermometer [59] shows that the Co-Ni-Fe sulphoarsenide formation temperature varies considerably: Lupikko-420-500 ${ }^{\circ} \mathrm{C}$, Hopunvaara-300-480 ${ }^{\circ} \mathrm{C}$, Herberz-1 $\sim 300^{\circ} \mathrm{C}$. The temperatures shown by the arsenopyrite thermometer are [60]: Herbertz-2340-450 ${ }^{\circ} \mathrm{C}$, Hopunvaara, Arsenic Shaft-380-430 ${ }^{\circ} \mathrm{C}$; Lupikko-340-480 ${ }^{\circ} \mathrm{C}$. Widespread "chalcopyrite dissease" in sphalerite from PMD ore suggests temperatures of no less than $334{ }^{\circ} \mathrm{C}$ [61] and up to $500{ }^{\circ} \mathrm{C}$ [62]. Star-like sphalerite aggregates, often identified in Pitkäranta ores, suggest sphalerite crystallization at a temperature of $>500{ }^{\circ} \mathrm{C}$ as a modification of $\alpha$-chalcopyrite characterized by the higher solubility of $\mathrm{ZnS}$ in it [63]. Relics of löllingite in arsenopyrite from Arsenic Shaft ores indicate a temperature of $400-500{ }^{\circ} \mathrm{C}$ and $\log \mathrm{fS}_{2}$ of about -10 [64]. A temperature of $350-380^{\circ} \mathrm{C}$ for electrum-sphalerite paragenesis in Lupikko ores, calculated with a corresponding thermometer [65] was found to be unusually high. The formation temperatures of beryllium mineralization, estimated from the homogenization temperature of fluid inclusions in phenakite, which replaces helvite, are estimated at 330-340 ${ }^{\circ} \mathrm{C}$ [66]. The chlorite thermometer [67] shows that the temperature of hydrothermal-metasomatic alterations at a propylitik stage for PMD deposits varies from 230 to $290^{\circ} \mathrm{C}$. Curiously, the lowest temperatures were yielded by high-Fe chlorites similar to thuringite-bavalite most commonly found to be associated with gold and silver minerals. The common presence of Au-Ag-Bi-Te-S low-temperature mineral association (32 minerals) in the metasomatic rocks studied suggests that ore formation took place also at temperatures much lower than those estimated by geothermometry methods $\left(<200{ }^{\circ} \mathrm{C}\right)$.

The great diversity of rare-metal ore mineralization (native metals, oxides and hydroxides, carbonates, tellurides, sulfides, sulfosalts, borates, and silicates) in PMD ores are also indicative of marked variations in $\log \mathrm{fO}_{2}$ and $\log \mathrm{fS}_{2}$ upon its formation. Apparently, bismuth sulfosalts, tellurides, and roquesite crystallized from solutions with a high Bi-Te-Se content under various temperature conditions and possibly during the decay of previously formed minerals of solid solutions containing $\mathrm{Bi}, \mathrm{Ag}$, Te, Se, In, Zn, and $\mathrm{Sn}$.

Bismuth sulfosalts in PMD ores occur as Ag-bearing phases (matildite, angelaite, pavonite, arcubisite, argentian wittite), copper sulfosalts (wittichenite, emplectite), bismuthine-aikinite series sulfosalts (aikinite, gladite, pekoite), and nickel sulfosalt (parkerite). They are associated with native bismuth, bismuthinite, bismite, bismuthite, and zavaritskite. Most mineral associations of bismuth sulfosalts form over a wide temperature range of 200 to $400{ }^{\circ} \mathrm{C}$ [68-72]. According to A.A. Godovikov [68] emplectite can be used for them as a maximum geothermometer, because at a temperature of $360-383{ }^{\circ} \mathrm{C}$ it is decomposed to wittichenite and cuprobismuthite, and the wittichenite formation temperature is not higher than $350-400{ }^{\circ} \mathrm{C}$ [68]. When associated with chalcopyrite, it is stable at a temperature below $395{ }^{\circ} \mathrm{C}$, and when associated with emplectite, at less than $318^{\circ} \mathrm{C}$ [73].

Matildite, commonly occurring as subhexagonal and xenomorphic grains, seems to be one of low-temperature Ag sulfobismuthides in PMD skarns. The ores contain no thinly tabular and reticulate matildite aggregates typomorphic upon the decomposition of solid $\alpha-\mathrm{AgBiS}_{2} \leftrightarrow \mathrm{PbS}$ solution at temperatures below $230-175^{\circ} \mathrm{C}$ [74] and upon the inversion of $\alpha-\mathrm{AgBiS}_{2} \rightarrow ß-\mathrm{AgBiS}{ }_{2}$ at a temperature of $174-182{ }^{\circ} \mathrm{C}$ [75]. This suggests its crystallization directly from hydrothermal solutions, possibly together with galena, at a temperature below $215-220^{\circ} \mathrm{C}$, a boundary temperature for $\alpha \rightarrow ß$ inversion of matildite [68]. There is another interpretation of matildite aggregates: they could have produced by the decomposition of chalcopyrite containing isomorphic $\mathrm{Ag}$ and $\mathrm{Bi}$ impurities at a temperature below $220{ }^{\circ} \mathrm{C}[76,77]$ and the average sulfidation conditions of solutions after [78]. Kitelä ores occasionally contain schapbachite-a high-temperature cubic phase of matildite containing up to $20 \% \mathrm{~Pb}$ (Table 6), which, according to the results of studies [79], is indicative of its formation temperature above $200{ }^{\circ} \mathrm{C}$.

Bismuthine-aikinite series sulfosalts in PMD ores are only represented by its endmembers: aikinite, gladite, pekoite, and bismuthinite (Figure 16). The latter is most common. Correspondingly, their aikanitic number [80]- $\mathrm{N}_{\mathrm{Aik}}=[2 \mathrm{~Pb} /(\mathrm{Pb}+\mathrm{Bi})]$ varies in two ranges: 101-120 for aikinite and 20-30 for gladite and pekoite. $\mathrm{N}_{\text {Aik }}$ values for aikinite 
exceeding 100 seems to be due to analytical errors caused by the micron size of aikinite aggregates and trapping of impurities. Aikinite is present in propylitized skarns with Fe$\mathrm{Cu}-\mathrm{Zn}$-Sn mineralization (Kitelä), while other minerals of this series occur in greisenized skarns with Fe-Zn-As-Sn-Be ores (Lupikko, Herberz-1, Arsenic Shaft). The absence of intermediate mineral phases of bismuthinite-aikinite series in Pitkäranta ores seems to be due to the discrete manifestation of ore processes caused by the multiple pulse-like supplies of hydrothermal solutions generated in each of six magmatic impulses that gave rise to the SARGB. In this case, the normal evolution of ore processes was disturbed at each stage, and the fluids generated by lithium-fluorine granites were responsible for a gap in the mineral formation of sulfosalts of bismuthinite-aikinitic series with the small-scale separation of only its extreme members (gladite and pekoite) in aposkarn greisens.

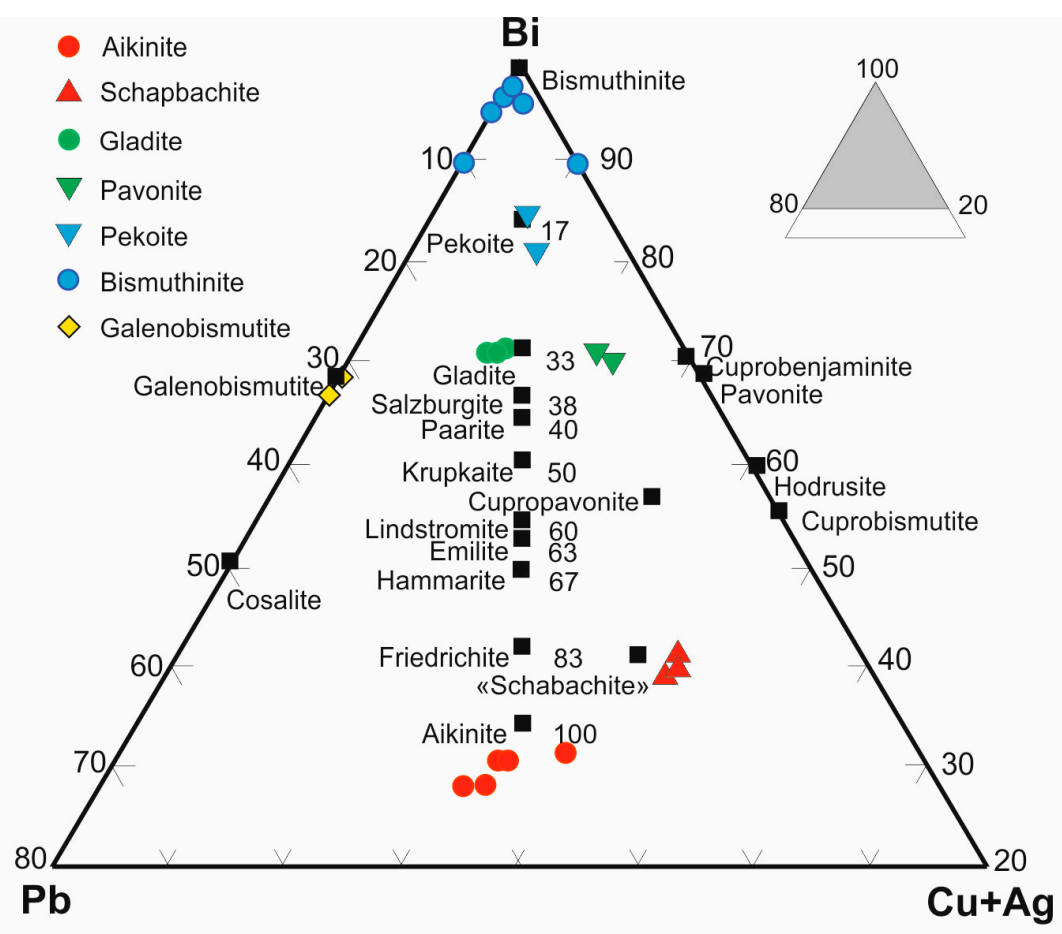

Figure 16. Ternary $\mathrm{Pb}-\mathrm{Bi}-(\mathrm{Cu}, \mathrm{Ag})$ diagram showing the composition of bismuthinite-aikinite series sulfosalts. Black squares show the ideal mineral compositions [80]. Numbers near the names of bismuthinite-aikinite series minerals indicate $\mathrm{N}_{\mathrm{Ai}}$ value $=[2 \mathrm{~Pb} /(\mathrm{Pb}+\mathrm{Bi})] \times 100$, after $[80]$.

The morphological diversity (single grains, micro inclusions, streaks, rims with micronsized streaky ramifications, films, intergrowths, and drop-like units) of native bismuth aggregates (Figure 6a,c) suggests that bismuth formed later than the major ore minerals of PMD skarns and that it was repeatedly remobilized and converted to molten condition. It occurs as micron-sized inclusions in both relatively high-temperature minerals, such as löllingite, pyrrhotite, and magnetite, and in low-temperature minerals, e.g., bornite, fluorite, and serpentine. It forms intergrowths with a variety of ore minerals: sphalerite, covellite, laitakarite, bismuthinite, altaite, and acanthite. These relationships of native bismuth with various minerals seem to be due to multiple fluid-thermal effects on the skarn ores of the SARGB pluton, which was forming discretely during six magmatic pulses which covered a period of 17 million years [5]. In this case, bismuth could collect, concentrate, and localize Au following the Liquid Bismuth Collector Model [81-84]. Single analyses show that PMD ores contain $>1 \mathrm{ppm}$ of gold and that there are electrum inclusions in native bismuth. Native gold and kurilite, an Au-bearing mineral, associated with bismuth are occasionally encountered.

Helvite-group minerals in the PMD were found only in aposkarn greisens. The bizarre composition of this group of minerals $(\mathrm{Mn}, \mathrm{Fe}, \mathrm{Zn})_{4}\left(\mathrm{Be}_{3} \mathrm{Si}_{3} \mathrm{O}_{12}\right) \mathrm{S}$, in which the 
orthosilicate and sulfide of the metal are combined is responsible for the high sensitivity of these minerals to variations in the fugacity of $\mathrm{O}_{2}$ and $\mathrm{S}_{2}$ and the activity of phenacite [85]. Therefore, the conditions conducive to the formation of helvite-group minerals are limited by the fairly narrow parameters of $\log \mathrm{fO}_{2}$ and $\log \mathrm{fS}_{2}$ values and depend on mineral associations [58]. Such ore-forming conditions in Pitkäranta skarns could exist only at the final stages of their hydrothermal-metasomatic alterations triggered by lithium-fluorine granites. Roquesite mineralization seems to have taken place under similar conditions.

All indium minerals, including roquesite, occur very seldom in nature, although elevated In concentrations have been revealed in base metal ores at many deposits. Therefore, conditions limiting the formation of indium minerals, including roquesite, are widely discussed in the modern geological literature [21,22,86,87].

Roquesite and In distribution in the ores and sphalerite (a major In concentrator mineral) of PMD deposits exhibit a certain pattern of its own. ICP MS and LA-ICP-MS analyses show that the highest average In concentrations in the ore $(\sim 500 \mathrm{ppm})$ and in sphalerite $(\sim 3200 \mathrm{ppm})$ are characteristic of roquesite-free propylitized skarns with Fe-Zn-Sn mineralization at the Kulismajoki occurrence, which is far from Li-F-granites (Figure 1). Roquesite occurs mainly in the greisen alteration zone of $\mathrm{Cu}-\mathrm{Zn}-\mathrm{Sn}$ skarns with abundant arsenopyrite-löllingite mineralization and an average In concentration of $\sim 300 \mathrm{ppm}$ in the ore and $\sim 500 \mathrm{ppm}$ in sphalerite. Such skarn alteration areas are spatially confined to Li-F granite units at sites where the top of the Salmi massif plunges gently with sharp bends (Hopunvaara, Arsenic Shaft). The biggest numerous roquesite aggregates, consisting dominantly of micron-sized streaks with stannoidite in chalcopyrite, which has undergone the decay of solid solution with separation of stannite, and grains at the sphalerite-chalcopyrite boundary (Figure 5) suggest that its formation was contributed to by indium released upon the decay of In-bearing solid sphalerite- $\left(\mathrm{Cu}^{1+} \mathrm{In}^{3+}\right) \leftrightarrow$ $\left(\mathrm{Zn}^{2+}, \mathrm{Fe}^{2+}\right)$ and chalcopyrite- $\mathrm{In}^{3+} \leftrightarrow \mathrm{Fe}^{3+}$ and $2 \mathrm{Fe}^{3+} \leftrightarrow\left(\mathrm{Fe}^{2+}, \mathrm{Zn}^{2+}\right) \mathrm{Sn}^{4+}$ solutions. The existence of a wide range of such solid solutions has been shown by Z. Johan [88], N. Cook et al. [21], and E. Ohta [51]. It is most probable that solid In solutions in sphalerite and chalcopyrite decayed to form roquesite at a lithium-fluorine granite intrusion stage, which completed the formation of the multi-phase SARGB. Roquesite grains commonly adjoin micron-sized fluorite veinlets filling fractures in chalcopyrite and sphalerite or contacts between them (Figure 5). The formation temperature of roquesite associated with chalcopyrite, sphalerite, stannine, and stannoidite, shown by a stannine-sphalerite geothermometer [49,50], varies from 270 to $320^{\circ} \mathrm{C}$. However, scarce finds of roquesite in intergrowths with hessite (Figure $5 \mathrm{~g}$ ) and galena (Figure $5 \mathrm{f}$ ) suggest its late formation under lower-temperature conditions at low $\mathrm{Zn}$ concentration in fluids.

Geochronological data $[5,29]$ show that there were probably two stages of $\mathrm{Fe}-\mathrm{Cu}$ Zn-Sn mineralization in PMD skarns: $1558 \pm 30$ Ma and $1546 \pm 28$ Ma. The age of aposkarn greisens (with roquesite mineralization, as became clear later), estimated by the $\mathrm{Sm}-\mathrm{Nd}$ isochrones method for minerals, is $1492 \pm 25$ Ma [29], i.e., they formed with a minimum time of $13 \mathrm{Ma}$ separating it from the crystallization of the latest rapakivi granites $(1530 \pm 0.6 \mathrm{Ma})$. Consequently, roquesite mineralization associated with the SARGB, like that in the Vyborg rapakivi massif [15,21], took place upon the formation of greisens and was a small-scale event, while economic indium resources of $\sim 2400 t[13,14,23]$ in the PMD are concentrated in $\mathrm{Sn}-\mathrm{Cu}-\mathrm{Zn}$ skarn ores, in which sphalerite is a major In concentrator mineral (maximum In concentration is 1.5\%, average In concentration from 174 analyses is $2001 \mathrm{ppm})$.

\section{Conclusions}

Rare-metal mineralization in the ores of skarn deposits in the PMD is mainly represented by In, Bi, Be, Te, and Se. It is consistent in the diversity of mineral varieties to that of skarn deposits, in which the cessation of ore formation was paralleled by the formation of low-temperature metasomatic rocks (propylites, serpentinites, etc.) with the well-defined 
ore-geochemical association $\mathrm{Au}-\mathrm{Bi}-\mathrm{Ag}$-Te-As, and deposits with aposkarn metasomatic rocks such as fluorite-enriched greisens with Be minerals and roquesite.

The distribution pattern of rare-metal mineralization in PMD skarn ores, its composition, and relationships with other minerals was controlled by the discrete manifestation pattern of ore processes affected by the multiple pulse-like supply of hydrothermal solutions generated in each of six magmatic impulses that gave rise to the SARGB. The normal evolution of ore processes was disrupted at each of these stages. As a result, fluids associated with lithium-fluorine granites were responsible for the final mineralization pattern known at present.

The absence of solid solution decomposition structures in sulphobismuthides from PMD ores indicates that they mainly crystallized from hydrothermal solutions at low temperatures.

The morphological features of native bismuth and its association with Ag-and Aubearing sulphobismuthides, and in a few cases with electrum, could indicate the development of an ore process, which is consistent to some extent with the Liquid Bismuth Collector Model.

Roquesite in PMD ores formed upon the greisen alteration of skarns and was contributed to by indium released upon the decay of In-bearing solid sphalerite- $\left(\mathrm{Cu}^{1+} \mathrm{In}^{3+}\right)$ $\leftrightarrow\left(\mathrm{Zn}^{2+}, \mathrm{Fe}^{2+}\right)$ and chalcopyrite- $\mathrm{In}^{3+} \leftrightarrow \mathrm{Fe}^{3+}{ }_{\mathrm{n} 2 \mathrm{Fe}^{3+}} \leftrightarrow\left(\mathrm{Fe}^{2+}, \mathrm{Zn}^{2+}\right) \mathrm{Sn}^{4+}$ solutions. Sphalerite with an average In concentration of $2001 \mathrm{ppm}$, rather than roquesite, is a major In-concentrating mineral. Predicted In resources in PMD sphalerite ores are estimated at $2400 \mathrm{t}$.

Funding: This research was funded by state assignment to the Institute of Geology Karelian Research Centre, RAS AAAA-A18-118020290175-2.

Institutional Review Board Statement: Not applicable.

Informed Consent Statement: Not applicable.

Data Availability Statement: Data is contained within the article.

Acknowledgments: A.N. Ternovoy is thanked for their assistance during the microprobe work. I am grateful to the reviewers, Academic Editor and S.A. Svetov for numerous helpful comments and recommendations that helped to improve this paper. I thank the Guest Editors Vasilios Melfos and Panagiotis Voudouris for the invitation to write this article for the special issue "Ore Mineralogy and Geochemistry of Rare Metal Deposits" and the advices. I wish also to thank G.N. Sokolov for her English corrections.

Conflicts of Interest: The author declares no conflict of interest.

\section{References}

1. Furman, G. Mineralogical description of part of Old and New Finland. Gorn. Z. 1828, II, 3-39. (In Russian)

2. Trüstedt, O. Die Erzlagerstätten von Pitkäranta am Ladoga-See. Helsingfors, Frenckellska tryckeriaktiebolaget. Bull. Commision Géologique Finl. 1907, 19, 333.

3. Iossa, G. News of finding tin and copper in Pitkäranta, Finland. Gorn. Z. 1834, IV, 157-161. (In Russian)

4. Amelin, Y.; Beljaev, A.; Larin, A.; Stepanov, K. Salmi Batholith and Pitkaranta ore Field in Soviet Karelia. In Rapakivi Granites and Related Rocks Symposium; Haapala, I., Ramo, O.T., Eds.; GSF: Salonsaari, Finland, 1991; p. 57.

5. Larin, A.M. Rapakivi Granites and Associated Rocks; Nauka: St. Petersburg, Russia, 2011; p. 402. (In Russian)

6. Nefedov, Y.I. Berborite: A new mineral. Dokl. Acad. Nauk SSSR Earth Sci. Sect. 1967, 174, 189-192. (In Russian)

7. Britvin, S.N.; Antonov, A.A.; Krivovichev, S.V.; Armbruster, T.; Burns, P.C.; Chukanov, N.V. Fluorvesuvianite, $\mathrm{Ca}_{19}\left(\mathrm{Al}_{1} \mathrm{Mg}, \mathrm{Fe}^{2+}\right)_{13}$ $\left[\mathrm{SiO}_{4}\right]_{10}\left[\mathrm{Si}_{2} \mathrm{O}_{7}\right]_{4} \mathrm{O}(\mathrm{F}, \mathrm{OH})_{9}$, a new mineral species from Pitkäranta, Karelia, Russia: Description and crystal structure. Can. Mineral. 2003, 41, 1371-1380. [CrossRef]

8. Pekov, I.V.; Gerasimova, E.I.; Chukanov, N.V.; Kabalov, Y.K.; Zubkova, N.V.; Zadov, A.E.; Yapaskurt, V.O.; Gekimyants, V.M.; Pusharovsky, D.Y. Hydroxyl chondrite $\mathrm{Mg}_{5}\left(\mathrm{SiO}_{4}\right)_{2}(\mathrm{OH})_{2}$ : A new gummite group mineral and its crystalline structure. Dokl. $R A N$. 2011, 436, 521-527. (In Russian)

9. Palmunen, M.K. Pitkäranta: vv. 1934-1938 suoritettujen vuoriteknillisten tutkimustenvalossa. Geol. Toimik. Geotek. Julk. 1939, 44, 154.

10. Nefedov, E.I. Mineralogy of the Pitkäranta Deposit: Metal Potential and Mineralogy of Skarnoids in South Karelia and in the Western Kola Peninsula; VSEGEI: St. Petersburg, Russia, 1973; 326p. (In Russian) 
11. Aleksandrov, S.M.; Troneva, M.L. Composition and genesis of endogenous borates from the Pitkäranta Ore Field, Karelia. Geokhimia 2009, 9, 972-987. (In Russian) [CrossRef]

12. Valkama, M. An Ore Petrological and Geochemical Study of the Polymetallic Skarn Ores at Pitkäranta. Geology and Mineralogy. Master's Thesis, Department of Geology, Faculty of Mathematics and Science, University in Turku, Turku, Finland, $2009 ;$ p. 85.

13. Ivashchenko, V.I.; Valkama, M.; Sundblad, K.; Golubev, A.I.; Alekseev, V.Y. New Data on Mineralogy and Metallogeny of Scarns in the Pitkyaranta Ore Region. Dokl. Earth Sci. 2011, 440, 1307-1311. [CrossRef]

14. Ivashchenko, V.I. Mineralogo-geochemical signs of the ore specialization of skarns from the Pitkäranta Ore Province (South Karelia, Russia) for rare and noble metals. Zap. RMO 2016, 2, 74-95. (In Russian)

15. Valkama, M.; Sundblad, K.; Cook, N.J.; Ivashchenko, V.I. Geochemistry and petrology of the indium-bearing polymetallic skarn ores at Pitkäranta, Ladoga Karelia, Russia. Miner. Dep. 2016, 51, 823-839. [CrossRef]

16. Sudovikov, N.G. Problems in Rapakivi and Late Orogenic Intrusions; Nauka: Moscow, Russia, 1967; p. 118. (In Russian)

17. Isokangas, P. Suomen malmeista ja niiden etsimisestä. Geologi 1976, 28, 1-9.

18. Törnebohm, A.E. Om Pitkäranta malmfält och dess omgifningar. Geol. Fören. Stockh. Förh. 1891, 13, 313-334. [CrossRef]

19. Bettencourt, J.S.; Tosdal, R.M.; Leite, W.B.; Payolla, B.L. Mesoproterozoic rapakivi granites of the Rondonia Tin Province, southwestern border of the Amazonian craton, Brazil-Reconnaissance U-Pb geochronology and regional implications. Prec. Res. 1999, 95, 41-67. [CrossRef]

20. Bettencourt, J.S.; Leite, W.B.; Goraieb, C.L.; Sparrenberget, I.; Bello, R.M.S.; Payolla, B.L. Sn-polymetallic greisen-type deposits associated with latestage rapakivi granites, Brazil: Fluid inclusion and stable isotope characteristics. Lithos 2005, 80, 363-386. [CrossRef]

21. Cook, N.J.; Sundblad, K.; Valkama, M.; Nygård, R.; Ciobanu, C.L.; Danyushevsky, L. Indium mineralisation in A-type granites in southeastern Finland: Insights into mineralogy and partitioning between coexisting minerals. Chem. Geol. 2011, $284,62-73$. [CrossRef]

22. Valkama, M.; Sundblad, K.; Nygård, R.; Cook, N. Mineralogy and geochemistry of indium-bearing polymetallic veins in the Sarvlaxviken area, Lovisa, Finland. Ore Geol. Rev. 2016, 75, 206-219. [CrossRef]

23. Alexeyev, I.A.; Amantov, A.V.; Amantova, M.G.; Babichev, A.V.; Baltybaev, S.K.; Bugayenko, I.V.; Voinov, A.S.; Golubtsova, N.S.; Zhamaletdinov, A.A.; Zaitsev, S.V.; et al. Proterozoic Ladoga Structure: Geology, Deep Structure and Minerageny; Sharov, N.V., Ed.; KarRC, RAS: Petrozavodsk, Russia, 2019; p. 435. (In Russian)

24. Eskola, P. Around Pitkäranta. Ann. Acad. Sci. Fenn. Geol. Geogr. 1951, 3, 90.

25. Saksela, M. Zur Mineralogie und Entstehung der Pitkäranta-Erze. Bull. Com. Géol. Finl. 1951, 154, $182-230$.

26. Khazov, R.A. Geological Characteristics of Tin Mineralization in the Northern Ladoga Lake Area; Nauka: Leningrad, Russia, $1973 ;$ p. 87. (In Russian)

27. Nironen, M. The Svecofennian Orogen: A tectonic model. Precambrian Res. 1997, 86, 21-44. [CrossRef]

28. Eskola, P. The problem of mantled gneiss domes. Geol. Soc. Lond. Q.J. 1949, 104, 461-476.

29. Larin, A.M.; Amelin, Y.V.; Neymark, L.A. Age and genesis of complex skarn ores in the Pitkäranta Ore Province. Geol. Rudn. Mestorozh. 1991, 6, 15-33. (In Russian)

30. Neymark, L.A.; Amelin, Y.V.; Larin, A.M. Pb-Nd-Sr isotopic and geochemical constraints on the origin of the 1.54-1.56 Ga Salmi rapakivi granite-anorthosite batholith (Karelia, Russia). Mineral. Petrol. 1994, 50, 173-193. [CrossRef]

31. Amelin, Y.V.; Larin, A.M.; Tucker, R.D. Chronology of multiphase emplacement of the Salmi rapakivi granite-anorthosite complex, Baltic Shield: Implications for magmatic evolution. Contrib. Mineral. Petrol. 1997, 127, 353-368. [CrossRef]

32. Ramo, O.T.; Manttari, I.; Vaasjoki, M.; Upton, B.G.J.; Sviridenko, L.P. Age and signifi cance of Mesoproterozoic CFB magmatism, Lake Ladoga region, NW Russia. Geol. Soc. Am. Abstr. Programs 2001, 33, 6.

33. Dukhovsky, A.A.; Artamonova, N.A.; Ivanova, E.I.; Nikoforov, I.O. 3D model of the Salmi rapakivi granite massif and the distribution pattern of mineralization. Reg. Geol. Metal. 1994, 4, 24-32. (In Russian)

34. Ivashchenko, V.I. Skarn Mineralization of Tin and Tungsten in the Southern Baltic Shield: Mineralogy, Petrography and Genesis; Nauka: Moscow, Russia, 1987; p. 240. (In Russian)

35. Larin, A.M. Zonation pattern of mineralization in the Pitkäranta District. Bull. Mosc. Nat. Geol. Sec. 1980, 55, 73-82. (In Russian)

36. Ivashchenko, V.I. Characteristics of skarn formation and acid leaching of skarns at the dolomitic contacts of rapakivi. Dokl. Acad. Nauk SSSR 1982, 267, 199-202. (In Russian)

37. Sundblad, K. Lead isotopic evidence for the orgin of 1.8-1.4 Ga ores and granitoids in the southeastern part of the Fennoscandian shield. Precambrian Res. 1991, 51, 265-281. [CrossRef]

38. Nikolskaya, Z.D.; Gordienko, L.I. Petrology and Metallogeny of Karelia's Granitoid Formations; Nedra: Moscow, Russia, $1977 ;$ p. 152. (In Russian)

39. Nikolskaya, Z.D.; Larin, A.M.; Kairyak, A.I. Appraisal of the Pitkäranta Ore Province's potential based on metasomatic zonation. Razved. Okhrana Nedr. 1977, 9, 17-20. (In Russian)

40. Khazov, R.A. Metallogeny of the Ladoga-Bothnian Geoblock, Baltic Shield; Nauka: Leningrad, Russia, 1982; p. 190. (In Russian)

41. Republic of Karelia's Mineral Potential; Mikhailov, V.P.; Aminov, V.N. (Eds.) Karelia: Petrozavodsk, Russia, 2005 ; Volume 1, p. 278. (In Russian)

42. Amelin, Y.V.; Neymark, L.A. Problems in Interpretation of Sm-Nd Model Ages. In Metody Izotopnoi Geologii; IGGD RAN: St. Petersburg, Russia, 1991; pp. 11-14. (In Russian) 
43. Amelin, Y.; Larin, A. U-Pb and Sm-Nd Zircon and Garnet Geochronology of Skarn Formation Associated with Rapakivi Granite Magmatism: An Example of the Pitkaranta Ore District, Southeastern Karelia. In Anorthosites, Rapakivi Granites and Related Rocks. IGCP 290 and 315. Abstract; McGill Univ.: Montreal, QC, Canada, 1994; p. 1.

44. Larin, A.M.; Neymark, L.A.; Gorokhovsky, B.M.; Ovchinnikova, G.V. Relationship of complex skarn mineralization in the Pitkäranta Districy with rapakivi granites of the Salmi massif: Pb-isotope data. Izv. Acad. Nauk SSSR Ser. Geol. 1990, 5, 47-57. (In Russian)

45. Stein, H.J.; Markey, R.J.; Morgan, J.W.; Sundbland, K.; Larin, A.M. Re-Os Dating of Molybdenite: New Tools, New Applications, New Interpretations-An Example from Karelian Russia. EOS Trans. Am. Geophys. Union 1996, 77, 773-774.

46. Svetov, S.A.; Stepanova, A.V.; Chazhengina, S.Y.; Svetova, E.N.; Mikhailova, A.I.; Rybnikova, Z.P.; Paramonov, A.S.; Utitsina, V.L.; Kolodei, V.S.; Ekhova, M.V. Precise ICP-MS and LA-ICP-MS analysis of rock and mineral composition: Technique application and assessment of accuracy of the obtained results on the example of Early Precambrian mafic complexes. Tr. Karel. Nauchn. Tsentr Ross. Akad. Nauk. 2015, 7, 54-73.

47. Vernadsky, V. Notes on the distribution of chemical elements in the Earth's crust. Bull. Acad. Imp. Sci. St. Petersbourg VI Ser. 1910, IV, 1129-1148. (In Russian)

48. Erämetsä, O. Über die Verbreitung des Indiums in Finnischen Mineralen und über seine Trennung von anderen Metallen. Ann. Acad. Sci. Fenn. A 51 1938, 154, 1-91.

49. Nekrasov, I.J.; Sorokin, V.I.; Osadchii, E.G. Fe and Zn partitioning between stannite and sphalerite and its application in geothermometry. Phys. Chem. Earth 1979, 34, 739-742. [CrossRef]

50. Shimizu, M.; Shikazono, N. Iron and zinc partitioning between coexisting stannite and sphalerite: A possible indicator of temperature and sulfur fugacity. Miner. Dep. 1985, 20, 314-320. [CrossRef]

51. Ohta, E. Occurrence and Chemistry of Indium-containing Minerals from the Toyoha Mine, Hokkaido, Japan. Min. Geol. 1989, 39, 355-372.

52. Andreyeva, I.P.; Samsonova, N.N. Pitkäranta Ore Province: The Background. In History of the Museum and Its Collections; Vernadsky State Geological Museum RAS: Moscow, Russia, 2019; pp. 97-112. [CrossRef]

53. Pekov, I.V.; Vlasov, E.A.; Gerasimova, E.I. Pitkäranta Practical Mineralogy Course; MAX PRESS: Moscow, Russia, 2008; p. 60. (In Russian)

54. Kołodziejczyk, J.; Pršek, J.; Voudouris, P.; Melfos, V. Bi-sulphotellurides associated with Pb-Bi-(Sb \pm Ag,Cu,Fe) sulphosalts: An example from the Stan Terg deposit in Kosovo. Geol. Carpath. 2017, 68, 366-381. [CrossRef]

55. Mikulski, S. Gold mineralization within contact-metamorphic and shear zones in the "Zloty Jar" quarrythe Zloty Stok As-Au deposit area (Sudetes). Geol. Q. 1996, 40, 407-442.

56. Dimitrova, D.; Kerestedjian, T. Bismuth minerals in the postskarn sulphide-arsenide mineralization in the Martinovo iron deposit, NW Bulgaria. Geochem. Mineral Petrol. 2006, 44, 19-32.

57. Ilmen, S.; Alansari, A.; Baidada, B.; Maacha, L.; Bajddi, A. Minerals of the Ag-Bi-Cu-Pb-S system from the Amensif carbonatereplacement deposit (western High Atlas, Morocco). J. Geochem. Explor. 2016, 161, 85-97. [CrossRef]

58. Barton, M.D.; Young, S. Non-Pegmatitic Deposits of Beryllium: Mineralogy, Geology, Phase Equilibria and Origin. In Beryllium: Mineralogy, Petrology, and Geochemistry; Walter de Gruyter GmbH \& Co KG.: Berlin, Germany, 2019; pp. 591-692. [CrossRef]

59. Klemm, D.D. Synthesen und Analysen in den Dreiecks diagrammen FeAsS-CoAsS-NiAsS und FeS $2-\mathrm{CoS}_{2}-\mathrm{NiS}_{2}$. Neues Jahrb. Fuor Mineral. Abh. 1965, 103, 205-255.

60. Kretschmar, U.; Scott, S.D. Phase relations involving arsenopyrite in the system Fe-As-S and their application. Can. Miner. 1976, 14, 364-386.

61. Yund, R.A.; Kullerud, G. Thermal stability of assemblages in the Cu-Fe-S system. J. Petrol. 1966, 7, 454-488. [CrossRef]

62. Cook, N.J.; Ciobanu, C.L. Bismuth tellurides and sulphosalts from the Larga hydrothermal system, Metaliferi Mts., Romania: Paragenesis and genetic significance. Miner. Mag. 2004, 68, 301-321. [CrossRef]

63. Moh, G.H. Phase relations and mineral assemblages in the Cu-Fe-Zn-Sn-S system. Chem. Erde. 1975, 34, 1-61.

64. Barton, P.B.; Skinner, B.J. Sulfide Mineral Stabilities. In Geochemistryof Hydrothermal Ore Deposits; Barnes, H.L., Ed.; John Wiley \& Sons: New York, NY, USA, 1969; pp. 278-403.

65. Shikazono, N.A. Comparision of temperatures estimated from the electrum-sphalerite-pyrite-argentite assemblage and filling temperatures of fluid implications from epitermal Au-Ag vein-type deposits in Japan. Econ. Geol. 1985, 80, 1415-1424. [CrossRef]

66. Nikolskaya, Z.D.; Larin, A.M. Greysens of the Pitkäranta Ore Field. Zap. VMO 1972, 6, 290-297. (In Russian)

67. Caritat, P.; Hutcheon, L.; Walshe, J.L. Chlorite geothermometry: A review. Clays Clay Miner. 1993, 41, 219-239. [CrossRef]

68. Godovikov, A.A. Bismuth Sulphosalts; Nauka: Moscow, Russia, 1972; p. 303. (In Russian)

69. Feitzinger, G.; Paar, W. Gangförmige Gold-Silber-Vererzungen in der Sonnblickgruppe (Hohe Tauern, Karnten). Arch. Lagerstättenforschung Geol. Bundesanst. 1991, 13, 17-50.

70. Mladenova, V.; Kerestedjian, T.; Dimitrova, D. Ag-Cu-Pb-Bi mineralization from the Svishti Plaz gold deposit, Central Balkan Mountain, Bulgaria. Geochem. Mineral. Petrol. 2001, 38, 55-66.

71. Buzatu, A.; Damian, G.; Dill, H.G.; Buzgar, N.; Apopei, A.I. Mineralogy and geochemistry of sulfosalts from Baia Sprie ore deposit (Romania)—New bismuth minerals occurrence. Ore Geol. Rev. 2015, 65, 132-147. [CrossRef] 
72. Fuertes-Fuente, M.; Cepedal, A.; Lima, A.; Dória, A.; Ribeiro, M.A.; Guedes, A. The Au-bearing vein system of the Limarinho Deposit (Northern Portugal): Genetic constraints from Bi-chalcogenides and Bi-Pb-Ag sulfosalts, fluid inclusions and stable isotopes. Ore Geol. Rev. 2016, 72, 213-231. [CrossRef]

73. Sugaki, A.; Kitakaze, A.; Hayashi, K. Hydrothermal synthesis and phase relations of the polymetallic sulfide system, especially on the Cu-Fe-Bi-S system. In Materials Science of the Earth's Interior; Sunagawa, I., Ed.; Terrapub: Tokyo, Japan, 1984; pp. 545-583.

74. Wang, N. An experimental study of some solid solutions in the system $\mathrm{Ag}_{2} \mathrm{~S}-\mathrm{PbS}-\mathrm{Bi}_{2} \mathrm{~S}_{3}$ at low temperatures. Neues Jahrb. Miner. Mon. 1999, 5, 223-240.

75. Tesfaye, F.; Lindberg, D. Thermochemical properties of selected ternary phases in the Ag-Bi-S system. J. Mater. Sci. 2016, 51, 5750-5759. [CrossRef]

76. Foord, E.E.; Shawe, D.R. The Pb-Bi-Ag-Cu- $(\mathrm{Hg})$ chemistry of galena and some associated sulfosalts: A review and some new data from Colorado, California and Pennsylvania. Can. Miner. 1989, 27, 363-382.

77. Voudouris, P.; Melfos, V.; Spry, P.G.; Bonsall, T.A.; Tarkian, M.; Solomos, C. Carbonatereplacement Pb-Zn-Ag-Au mineralization in the Kamariza area, Lavrion, Greece: Mineralogy and thermochemical conditions of formation. Miner. Petrol. 2008, 94, 85-106. [CrossRef]

78. Einaudi, M.T.; Hedenquist, J.W.; Inan, E.E. Sulfidation state of hydrothermal fluids: The porphyry-epithermal transition and beyond. In Volcanic, Geothermal and Ore-Forming Fluids: Rulers and Witnesses of Processes Within the Earth; Simmons, S.F., Graham, I.J., Eds.; Special Publications of the Society of Economic Geologists; Society of Economic Geologists: Littleton, CO, USA, 2003; Volume 10, pp. 285-313.

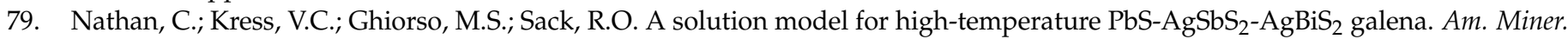
2008, 93, 1630-1640. [CrossRef]

80. Makovicky, E.; Makovicky, M. Representation of compositions in the bismuthinite-aikinite series. Can. Miner. 1978, 16, 405-409.

81. Douglas, N.; Mavrogenes, J.; Hack, A.; England, R. The Liquid Bismuth Collector Model: An Alternative Gold Deposition Mechanism. In Understanding Planet Earth; Searching for a Sustainable Future; on the Starting Blocks of the this Millennium Australian Geological Convention; Skilbeck, C.G., Hubble, T.C.T., Eds.; Geological Society of Australia: Brisbane, Australia, 2000; Volume 59, p. 135.

82. Tomkins, A.G.; Pattison, D.R.M.; Zaleski, E. The Hemlo Gold Deposit, Ontario: An Example of Melting and Mobilization of a Precious Metal-Sulfosalt Assemblage during Amphibolite Facies Metamorphism and Deformation. Econ. Geol. 2004, 99, 1063-1084. [CrossRef]

83. Ciobanu, C.L.; Cook, N.J.; Damian, F.; Damian, G. Gold scavenged by bismuth melts: An example from Alpine shear-remobilizates in the Highis_Massif, Romania. Miner. Petrol. 2006, 87, 351-384. [CrossRef]

84. Hastie, E.C.G.; Kontak, D.J.; Lafrance, B. Gold Remobilization: Insights from Gold Deposits in the Archean Swayze Greenstone Belt, Abitibi Subprovince, Canada. Econ. Geol. 2020, 115, 241-277. [CrossRef]

85. Burt, D.M. Stability of genthelvite, $\mathrm{Zn}_{4}\left(\mathrm{BeSiO}_{4}\right)_{3} \mathrm{~S}$ : An exercise in chalcophilicity using exchange operators. Am. Miner. 1988, 73, 1384-1394.

86. Dill, H.G.; Garrido, M.M.; Melcher, F.; Gomez, M.C.; Weber, B.; Luna, L.I.; Bahr, A. Sulfidic and non-sulfidic indium mineralization of the epithermal $\mathrm{Au}-\mathrm{Cu}-\mathrm{Zn}-\mathrm{Pb}-\mathrm{Ag}$ deposit San Roque (Provincia Rio Negro, SE Argentina)—With special reference to the «indium window» in zinc sulfide. Ore Geol. Rev. 2013, 51, 103-128. [CrossRef]

87. Murakami, H.; Ishihara, S. Trace elements of indium-bearing sphalerite from tin-polymetallic deposits in Bolivia, China and Japan: A femto-second LA-ICP MS study. Ore Geol. Rev. 2013, 53, 223-243. [CrossRef]

88. Johan, Z. Indium and germanium in the structure of sphalerite: An example of coupled substitution with copper. Miner. Petrol. 1988, 39, 211-229. [CrossRef] 